\title{
LÍMITES Y POSIBILIDADES DE LA ARQUEOLOGÍA DEL PAISAJE
}

\author{
LIMITS AND POSSIBILITIES OF THE ARCHAEOLOGY OF LANDSCAPE
}

\author{
por
}

FELIPE CRIADO BOADO

RESUMEN Se realiza una revisión teórica y epistemológica de la Arqueología del Paisaje. En ella se critica el concepto funcionalista, empirista y moderno de espacio utilizado en general dentro de esa línea de investigación. Esa crítica apunta sobre todo a la estrecha relación entre ese concepto y la noción capitalista de espacio (que entiende éste como el territorio de la explotación y la maximización económico-energética), y a su subordinación al concepto de tiempo dentro del sistema de saber moderno. A partir de esas puntualizaciones, se plantean algunas posibles alternativas teóricas e interpretativas para la Arqueología del Paisaje. Siguiendo modelos teóricos antropológicos y datos arqueológicos se definen cuatro regularidades principales de interrelación entre pensamiento, sociedad y espacio. Cada una de ellas muestra una actitud distinta hacia el ambiente y genera diferentes tipos de efectos sobre el paisaje: pasiva, participativa, doméstica y destructiva.

\footnotetext{
ABSTRACT This paper deals with a theoretical-epistemological review of Landscape Archaeology. It develops a critic of the "functionalist", "empiricist" and "modernist" concept of Space underlying such strategy of archaeological research. It is shown: (a) the strong relationship between that concept and the capitalist notion of space as a territory for exploitation and economo-energetic maximization, and (b) its subordination to Time within the system of knowledge of western Modernity. Bearing in mind these points, this paper points out some theoretical and interpretive alternatives for Landscape Archaeology. According to anthropological theoretic models and to archaeological data, four major classes of mind-society-space regularities are defined: hunting, savage, peasant and industrial-modern regularity. Each of them show a pasive, participative, domesticater and destructive attitude towards environment with different effects on landscape. In the transition from savage-participative attitude to peasant-domesticater stage emerges the monumental phenomenon, signifying the new socio-cultural situation.
} 


\section{INTENCIONES: TIEMPOS MODERNOS Y ESPACIOS PREHISTÓRICOS}

Este trabajo pretende satisfacer dos inquietudes fundamentales. Cada una de ellas pertenece a un orden distinto de discurso pero, al tiempo, no se puede plantear la una sin la otra '.

La primera intención que se abriga es realizar una crítica de la concepción moderna del espacio que se utiliza en la práctica arqueológica (apartado 1.). Esta crítica se centrará en aspectos teóricos y epistemológicos, dejando a un lado la revisión de los aspectos de orden metodológico y técnico que, además de pertenecer a una escala de análisis distinta y ulterior a la que esta reflexión pretende realizar, ha sido desarrollada convenientemente en otros puntos ${ }^{2}$. Este texto, por su parte, yendo más allá de lo aparente e inmediato, pretende realizar una arqueología (en sentido foucaltiano) del estudio arqueológico del espacio, lo que implica considerar dicha temática y disciplina desde el punto de vista más basto del sistema de saber-poder al que ambas pertenecen ${ }^{3}$. De este modo, este texto se apura como una contribución al intento de formular una teoría adecuada para pensar el espacio dentro de la práctica arqueológica.

La segunda intención de este trabajo es planter un modelo alternativo sobre la relación entre espacio y cultura que pueda ser rentable para la práctica arqueológica (apartado 2.). Esta alternativa es de orden esencialmente teórico, queriendo significar con ello que, después de la crítica anterior, se trata de formular un esquema que, aunque no exista ni haya existido en sentido concreto, establezca un marco de caracter general ante el cual fenómenos y elementos aislados podrían llegar a cobrar una significación nueva. En este sentido, el presente texto, yendo por donde no van las posiciones habituales en el estudio del espacio arqueológico, pretende recuperar un terreno de estudio dominado tradicionalmente por aproximaciones funcionalistas, economicistas y reduccionistas ${ }^{4}$. De este modo, este texto se apura además como una contribución al intento de generar una teoría que sirva para pensar la interrelación entre cultura, sociedad y espacio, entre sistemas de pensamiento, formaciones económico-sociales y paisaje.

En este sentido, el apartado 3., último de este trabajo, intentará reconstruir de forma somera las líneas generales de los principales paisajes arqueológicos que se pueden identificar en la Prehistoria gallega, partiendo para ello de los datos ofrecidos por la investigación prehistórica reciente y del modelo teórico que aquí se plantea.

1. El núcleo básico de este artículo está constituido por dos comunicaciones presentadas en el II Congreso Mundial de Arqueología, celebrado en Barquisimeto (Venezuela) en 1990. Entre las razones que retuvieron la publicación de este trabajo hasta la fecha se encontró nuestro deseo de dar tiempo a que investigaciones concretas abordadas durante estos años ofrecieran resultados con los que contrastar los planteamientos abstractos, y casi especulativos, de la formulación inicial. En poco tiempo estos resultados irán viendo la luz y a alguno de ellos nos referiremos a continuación. Quiero agradecer a todos los compañeros (véase nota 54) con los que durante estos años he colaborado con intenciones comunes, la ocasión de desarrollar estas investigaciones y de discutir sus resultados, a Almudena Hernando y Fidel Méndez la lectura del texto y las anotaciones que me hicieron sobre el mismo, y a Juan Vicent reconocer las múltiples conversaciones sin finalidad práctica alguna pero que están detrás de muchos de los argumentos aquí contenidos. Los dibujos han sido delineados por A. Rodríguez Paz, a quien además quiero expresar mi agradecimiento por su aptitud siempre imaginativa y profesional para buscar la mejor expresión gráfica de los argumentos y motivos que discutimos juntos.

2. Véase por ejemplo el trabajo de J. Vicent (1992) o también el volumen Wagstaff 1987.

3. El concepto de Arqueología de Foucault está sobradamente explicitado en Foucault 1979 y la noción de Sistema de Saber-Poder en Foucault 1980a, 1980c o 1980d. Sería muy interesante hacer una revisión de la rentabilidad de estos conceptos y posiciones para orientar la práctica arqueológica y la crítica de la misma, pero esa temática pertenece a un orden intencional que, aunque relacionado con el del presente trabajo, presenta una dimensión totalmente distinta.

4. Y que la Arqueología Espacial, en sus viejas y nuevas versiones, representa perfectamente (para una crítica de estas orientaciones y su consiguiente revisión bibliográfica nos remitiremos a Criado 1988 y al capítulo introductorio del volumen de Criado et al. 1991). 
En otros puntos se ha justificado la conveniencia de sustituir la Arqueología Espacial por una Arqueología del Paisaje, de dejar de hablar del espacio, para hablar en cambio del paisaje. Sin embargo, existen al menos tres formas distintas de entender este concepto. Una primera empirista, en la que el paisaje aparece como una realidad ya dada y que, por diferentes razones, se niega a sí misma; una segunda sociológica, que explica el paisaje como el medio y el producto de los procesos sociales, y que es la que sigue, por ejemplo, Vicent 1991; y una tercera socio-cultural, que lo interpreta como la objetificación de las prácticas sociales, tanto de carácter material como imaginario ${ }^{5}$. Este trabajo, por su parte, se debería entender ante todo como el esbozo de los planteamientos (teóricos) y las propuestas (interpretativas) generales que orientan el desarrollo de esta última línea de investigación.

\section{LÍMITES: LA ARQUEOLOGÍA ENTRE EL TIEMPO Y EL ESPACIO}

\subsection{El espacio del orden}

M. Foucault, haciendo de "arqueólogo de la Modernidad", muestra de qué modo, dentro de una situación histórica concreta, la emergencia de un nuevo sistema de saber, el que constituye el Orden Burgués u orden de la modernidad, implica una determinada tecnología política que se resuelve en una estrategia específica de producción de individuos (Foucault 1978, 1980a y 1980e: 89). Ahora bien, ese gigantesco mecanismo de producción de realidad social e individuos moviliza para ello recursos de muy diferente estilo, desde la emergencia de las ciencias humanas hasta la creación de espacios sociales determinados.

Concretamente Foucault, amparado en el principio de que "las técnicas de poder se han inventado para responder a las exigencias de la producción" (Foucault 1989: 23), ha examinado la relación entre poder y construcción del espacio a través de la utopía arquitectónica del Panóptico del arquitecto utilitarista J. Bentham, describiendo de qué modo ese modelo de organización espacial modela al individuo moderno (Foucault 1984, Bentham 1989/1822). En otro punto, revisa cómo el orden burgués ha construido los individuos que precisaba (obreros-soldados-escolares-presos) a través de una ordenación de sus vidas privadas operada a través de la construcción del espacio doméstico, y así enuncia los principios fundamentales en los que se podría basar una arqueología de los orígenes de la casa moderna, en la que ésta aparece como el recurso de una nueva tecnología de poder y que, con su énfasis en la intimidad compartimentada, es inseparable del nuevo concepto de hombre que desarrolla la modernidad (Foucault 1989: 13 y ss.).

A partir de este planteamiento surgen varias consecuencias relativas al espacio de gran rentabilidad y útiles, también, para la Arqueología. Detallaremos tres implicaciones principales:

(1) En primer lugar, a través de él se hace evidente no sólo la íntima relación entre espacio, pensamiento y sociedad, sino que, más allá del reconocimiento de esa circunstancia, se percibe que la construcción del espacio aparece como una parte esencial del proceso social de construcción de la realidad realizada por un determinado sistema de saber y que es, asímismo, compatible con la organización socio-económica y con la definición de individuo vigente en ese contexto; lo que significa, en definitiva, que el espacio es ante todo un tema histórico y político.

5. Esta referencia a los procesos de objetificación de las prácticas sociales se hace en un sentido semejante al que le otorga P. Veyne 1988. 
(2) En segundo lugar podemos admitir que esta relación, que Foucault estudia dentro de las sociedades europeas posteriores al siglo XVII, reaparecerá en cualquier cultura que consideremos, lo que supone reconocer que el espacio, en vez de ser una entidad física "ya dada", estática y mera ecología, es también una construcción social, imaginaria, en movimiento contínuo y enraizada con la cultura. De aquí se derivan una serie de implicaciones importantes para el estudio arqueológico del espacio sobre las que volveremos en la segunda parte de este trabajo.

(3) En tercer lugar, al reconocer que el concepto de espacio que utiliza nuestra cultura es una categoría dotada de un valor determinado por nuestro sistema de saber-poder, se nos impone la evidencia de que, en ese sentido, no puede ser utilizado sin más para esbozar reflexiones sobre el espacio en culturas diferentes de la nuestra. Al menos habría que tener presente esta posibilidad como hipótesis de partida e intentar descubrir de qué modo este concepto contextual de espacio podría interferir el estudio de otros espacios.

A continuación nos extenderemos sobre este último punto. Para ello, el planteamiento foucaltiano que seguimos, nos impele a:

(a) examinar la situación del concepto de espacio dentro del sistema de saber, observando sus relaciones y correspondencias con otros argumentos del pensamiento (apartado 1.3.);

(b) relacionar ese concepto de espacio con una particular dinámica socio-económica o, volviendo a la terminología de mayor resolución acuñada por Foucault, considerar la utilidad de dicho concepto de espacio dentro del sistema de poder del orden burgués atendiendo a las íntimas relaciones que se dan entre esa categoría y la de producción (apartado 1.2.).

\subsection{Espacio moderno y poder}

A pesar de la importancia que ha tenido el tema del espacio, en general dentro del pensamiento occidental ha existido una cierta miseria en torno a la reflexión sobre el espacio que se podría ilustrar con ejemplos diversos ${ }^{6}$, la mayor parte de los cuales muestran que durante mucho tiempo, y todavía ahora, se ha evitado considerar al espacio como "un problema histórico-político" (Foucault 1989: 12). En cambio el espacio fue normalmente entendido o bien como un problema natural, geográfico, o bien como un mero lugar de residencia y expansión de un pueblo o Estado (Foucault 1989: 12). De este modo el espacio quedó abocado a su comprensión bajo categorías deterministas y ecológicas, o a su utilización como territorio de dominio y explotación: "En suma, se lo analizaba o bien como suelo, o bien como aire; lo que importaba era el sustrato o las fronteras", (Foucault 1989: 12).

Ahora bien, esa noción de espacio no es inocente ni accidental, sino que, definida como está por una base y su límite, configura en realidad la idea del espacio capitalista y moderno y se concreta como condición infraestructural necesaria, o al menos conveniente, para el desarrollo de la revolución industrial y del capitalismo.

Braudillard ilustra cómo la creación de un concepto de Naturaleza que no existía antes, en el siglo XIX es "el revés de la entrada de la Naturaleza en la era de su dominación técnica" (1983: 54), y se constituye, acompañada de la escasez y la necesidad, en el anverso del concepto fundamental del orden burgués y de la economía política: la producción (1983: 57 y ss.). "Todo aquello que invoca a la Naturaleza, invoca la dominación de la Naturaleza" (1983: 24). A partir de este momento se impone un modelo de Naturaleza como territorio para el ejercicio de la producción y del sistema capitalista.

6. En este trabajo consideraremos varios ejemplos de miseria espacial; pero, en vez de tratarlos de modo conjunto, los introduciremos según lo reclame la lógica analítica y argumental del texto. 
De este modo, "el concepto se desdobla en una Naturaleza "buena", dominada y racionalizada (aquella que sirve de referencia ideal a la Cultura), y una Naturaleza "mala", hóstil, amenazante, catastrófica o contaminada" (1983: 57).

Esta misma genealogía de pensamiento y contexto socio-económico subyacen al proceso que Foucault define como instauración de un bio-poder, y en el cual la sexualidad juega un papel protagonista al generar una nueva anatomía política del cuerpo que, reforzando el proceso de individualización desarrollado por la sociedad disciplinaria ", se convierte en "un elemento indispensable en el desarrollo del capitalismo (ya que) éste no pudo afirmarse sino àl precio de la inserción controlada de los cuerpos en el aparato de la producción y mediante un ajuste de los fenómenos de población a los procesos económicos" (Foucault 1980a: 170). El bio-poder como tecnología nueva de poder quiere decir que la "vida entra en la historia", que "los fenómenos propios de la vida y de la especie humana entran en el orden del saber y del poder" (1980a: 171). A partir de este momento la vida aparecerá en el campo del saber bajo la doble y contradictoria dimensión de "entorno biológico de la historia" y de "interior de la historicidad humana", lo que hará que numerosas disciplinas que tratan desde la salud, la higiene o la alimentación. hasta las condiciones de vida o el entorno puedan presentarse como otras tantas tecnologías políticas (1980a: 174, la cursiva es nuestra).

Así pues, como reflexión acerca del entorno, la concepción del espacio y el concepto de espacio geográfico están en armonía con un sistema que necesita creer que la naturaleza es enemiga de la cultura, como paso previo para declararle la guerra y explotarla y producir más y más. Como dijera Lévi-Strauss criticando una célebre y ampliamente aceptada proposición de L. White: "el valor fundamental profesado por la Civilización Occidental es acrecentar contínuamente la cantidad de energía disponible" (1979: 325).

Esta consideración del espacio como naturaleza-para-explotar reduce al espacio a la dimensión de territorio, "es decir, al conjunto de las condiciones materiales de trabajo (la ciudad, el campo, etc..)". M. Quaini critica con dureza esta posición (1981: 74-5) que, según la opinión de otro autor, implica una concepción del espacio como medio "dominado por el hombre o, incluso, creado" y permite llegar a decir que "incluso el paraiso tuvo su empresario. La relación del hombre con la naturaleza, cada vez más, va siendo de dominación y control, por mucho que lo deploren los amantes de la vida natural", es una relación "entre un dueño y señor, que constantemente se va haciendo más numeroso, poderoso y progresivo, y un enorme siervo, cada vez más vulnerable y conservador" (Chorley 1975: 230-1 ${ }^{8}$ ).

En definitiva vemos que es la racionalidad burguesa la que construye un espacio finito, medible y real, ya que sólo estas características pueden permitir que aquello que se denomina espacio se pueda parcelar, repartir, expropiar, vender, explotar, destruir ${ }^{9}$. El espacio construido de acuerdo con esa racionalidad se puede definir como funcionalista, empírico y moderno.

Con el adjetivo funcionalista recojemos la noción simplista según la cual los hechos económicos y sociales originan un orden geométrico, espacial, a través del cual se traducen inequívocamente

7. Tema que Foucault trata en "Vigilar y castigar" (1984).

8. De ahí que este último autor relacione el auge de la Geografía Ambiental con la crisis ecológica de principios de los 70 y la preocupación en este sentido surgida de ella (1975b: 227), contexto en el que también eclosiona la Arqueología Ecológica-Espacio-Ambiental, evidencia que debería llegar para de-construir esta estrategia de trabajo.

9. Este tipo de invención del espacio queda bien ejemplificada en las palabras de un geógrafo: "el espacio geográfico es localizable, concreto, diríamos "trivial"”, es el "soporte de un sistema de relaciones" (Dollfus 1976: 8), "organizadas" que proceden del medio físico o de las sociedades humanas (1976: 123). 
aquellos; en esta presunción, que ha sido puesta en entredicho por ciertas ramas de la Nueva Geografía $^{10}$, se apoyan la mayor parte de las aplicaciones clásicas de la Arqueología Espacial ".

Con el adjetivo empírico indicamos la convicción de que el espacio sea transparente a la observación científica, admitiendo que se puede medir, cuantificar y objetivar.

$\mathrm{Y}$ con el adjetivo moderno (también se podría decir positivista) significamos el reconocimiento de que esa observación es generalizable, de que en base a ella se pueden enunciar leyes y predecir resultados y destacamos el convencimiento de que es posible formular un discurso nomotético de validez universal sobre el espacio.

Evidentemente los dos últimos puntos configuran la base de todas las ciencias naturales que tienen como objeto al espacio. Nuestra intención ahora no es relativizarlas como tales discursos sobre la naturaleza sino, a partir de la convicción post-moderna de que ya no es posible encontrar un principio de validación universal que permita juzgar la certeza de nuestros juicios ${ }^{12}$, cuestionar cualquier discurso sobre el espacio social que pretenda poseer rango globalizador.

Un buen ejemplo en este sentido, que por otra parte ilustra la miseria de un pensamiento espacial incapaz de reconocer los hechos culturales y la realidad multiforme de la práctica social, lo aportan las disciplinas de ordenación del medio y planificación del territorio. En efecto, sin duda es cierto que se puede proponer una clasificación y ordenación del medio según criterios objetivos ${ }^{13}$. Lo que no es en absoluto cierto es que esos criterios, que normalmente responden a racionalidades económicas maximizadoras de beneficios y propias de una economía de mercado, sean los únicos o los más válidos, ya que esos criterios generalmente entran en contradicción con comunidades y con prácticas económicas tradicionales y consideradas "antiguas" 14

A partir de aquí se debería evitar la utilización en el análisis espacial de categorías, modelos y medios cartográficos, o de otro tipo, generados a partir de nuestra óptica burguesa maximizadora del medio. En cambio deberíamos empezar a utilizar criterios y categorías que pretendieran estar próximas a las que habrían poseido aquellos seres, otros individuos culturales, cuya existencia pretendemos

10. Por ejemplo Claval 1981: 212; sin embargo algunos geógrafos aún pretenden soslayar este problema aumentado los datos documentales, perfeccionando los modelos y métodos matemáticos, y destacando la imperfección del hombre y la irracionalidad de sus actos como forma de justificar la imposibilidad de concebir explicaciones normativistas (Claval 1981: 213 y ss.).

11. Noción que rechazan todos aquellos arqueólogos más preocupados por definir un "espacio social" que por reconocer un "espacio formal": "la territorialidad de una sociedad no es su reflejo, toda vez que es tanto su base como su efecto" (Nocete 1989: ix).

12. La riqueza de la reflexión en este sentido es muy rica dentro del pensamiento que se define como post-moderno, por más que sobre esta etiqueta, su valor y su uso como alternativa dentro del campo de nuestra cultura habría mucho que decir; se puede ver como trabajo sintético Lyotard 1988.

13. En este principio se basan todas las oficinas públicas y empresas privadas de gestión del territorio, y aquí radican en gran medida las causas del fracaso social de las políticas medio-ambientales.

14. Frente al principio anterior se puede argüir, por ejemplo, que un suelo no es ni malo ni bueno en términos absolutos, sino que es malo o bueno dependiendo del sistema tecnológico en el que se introduzca, de las imposiciones que se deriven de su régimen de propiedad o de las relaciones sociales que en relación con él se desarrollen. Defender lo contrario es generar un discurso moderno y burgués de caracter ideológico. Ahora bien, esto, que es una observación que en principio compartirían muchos analistas, es también algo que se olvida continuamente. En Arqueología, por ejemplo, se oculta esta problemática cuando se utilizan mapas de utilización del suelo realizados desde perspectivas modernas para "racionalizar" el poblamiento prehistórico. En Galicia (pais húmedo y atlántico, de topografía accidentada y sustrato fundamentalmente granítico), el régimen de drenaje del suelo puede ser un factor limitante o maximizador de la calidad del suelo de diferente valor según éste se aplique a la explotación de ganado vacuno, al cultivo con maquinaria pesada, al cultivo intensivo con arado y tracción animal, al cultivo tradicional de rozas o al cultivo de azada de tipo neolítico. 
conjurar mediante el análisis. Esta alternativa metodológica es particularmente rentable en aquellos casos en los que todavía existe un sistema agrario "tradicional" que ofrece una analogía de un orden totalmente distinto para desarrollar el análisis ${ }^{15}$.

\subsection{Espacio y saber moderno}

Este somero análisis permite, creemos, valorar el significado contextual del concepto de espacio y descubrir algunas de sus limitaciones. En este sentido se percibe mejor la situación de miseria espacial que enunciábamos al principio. Pero todavía no comprendemos completamente el por qué de esa miseria. Para apurar esta lectura, deberemos dejar de mirar al contexto socio-económico, a la vertebración entre éste y el sistema de saber del orden burgués, y acudir en cambio a la economía interna de ese saber.

En el pensamiento clásico de la modernidad existe una oposición tajante entre prioridad del tiempo y descrédito del espacio. El espacio se identificó con lo muerto y lo inmóvil, en tanto el tiempo era rico, vivo, fecundo (Foucault 1980b: 117). En este sentido el espacio pasó a ser reaccionario y el tiempo, en cambio, progresivo ${ }^{16}$.

Ahora bien, esta oposición no se da sin más, sino que, siguiendo a Bermejo Barrera (1987: 214), se debe entender como un episodio más del proceso de nacimiento y fundamentación dentro de nuestra cultura del concepto de sujeto, pilar básico del sistema de saber moderno. La instauración del sujeto se realizó a través de la separación radical de cuerpo y espíritu, separación que se convertía en una lucha del espíritu contra el cuerpo y sus instintos, lucha que culminaba con la hegemonía del primero en detrimento de los segundos. Al mismo tiempo, y dentro de una tradición de pensamiento que se remonta hasta Grecia, el cuerpo se equiparaba con el espacio, con la materialidad, las sensaciones y los placeres, en tanto el espíritu, correlato de Dios y del sujeto, se identificaba con el tiempo ${ }^{17}$. El tiempo y la historia, mejor que el espacio y la naturaleza, permitían fundamentar la función fundadora del sujeto, ya que de este modo, la permanencia de una conciencia a través y a pesar del devenir temporal, permitía establecer una identidad suprahistórica y de caracter teleológica "que tendría por función recoger, en una totalidad bien cerrada sobre sí misma, la diversidad al fin reducida del tiempo" (Foucault 1979: 18-22).

De resultas de todo este proceso, dentro de la configuración del saber de la sociedad blanca, la perpetuación del espíritu a través del tiempo, su victoria sobre la contingencia y la cotidianidad, precisó pagar un precio elevado: condenar al espacio a una consideración semejante a la que la moral tradicional arrojó sobre el cuerpo y los instintos. Las consecuencias de este proceso son conocidas. En lo que al cuerpo se refiere hizo falta que Freud psicoanalizara a toda una cultura para poner a ésta nuevamente en armonía con sus cuerpos.

15. El valor de esa analogía estriba en que, aunque siga estando lejos de la racionalidad subjetiva de la sociedad que se pretende estudiar, está asímismo lejos del modelo de subjetividad "burguesa" y evita, por lo tanto, una reificación inconsciente de la misma a través del estudio.

16. "Será necesario hacer una crítica de esta descalificación del espacio que reina desde hace varias generaciones. ... El espacio es lo que estaba muerto, fijado, no dialéctico, inmóvil. Por el contrario el tiempo era rico, fecundo, vivo, dialéctico" (Foucault 1980b: 117). "Esta doble ocupación del espacio por una tecnología política y por una práctica científica ha circunscrito la filosofía a una problemática del tiempo. Desde Kant, lo que el filósofo tiene que pensar es el tiempo, con una descalificación correlativa del espacio que aparece del lado del entendimiento, de lo analítico, de lo conceptual, de lo muerto, de lo fijo, de lo inerte" (Foucault 1989: 12-3).

17. Véase en general sobre esta problemática Bermejo 1987, libro I1: 117-216. 
Pero las consecuencias no fueron menores para el espacio. A raiz de este proceso se afianzó una miseria espacial que hizo que el debate sobre el espacio fuese siempre suplantado por el tiempo. Ejemplo de ello lo ofrece una ciencia de la vida, como la biología, que a través del evolucionismo antes de ser el enraizamiento de la existencia en referencias espaciales, es su enmarcamiento en sucesiones temporales.

También en las disciplinas históricas se percibe con claridad este influjo negativo ${ }^{18}$. Es bien sabido que la miseria de las posiciones fenomenológicas utilizadas para fundamentar la Historia radica en que, allí donde se establece la razón de sus posibilidades, allí mismo se introduce la razón de sus límites: a través de Heidegger el sujeto no sólo existe en el tiempo, sino que sobre todo es en sí tiempo. Si ello fuera cierto, entonces desde el sujeto se podría reconocer la Historia a pesar de las limitaciones derivadas de la posición del historiador dentro de un presente particular, pero en la medida en que ese presupuesto es una operación dogmática, desde aquél sólo se puede reconstruir subjetivamente aquella. Como es bien sabido, esta actitud, bajo la extrapolación de los valores inherentes a una determinada posición histórica, conduce a la universalización de una subjetividad contextual.

En este tipo de trampa ha caido recientemente la Arqueología Post-procesual en su rama hermenéutica (Hodder 1986 y 1991). Aunque este punto ha sido destacado por los críticos condenando (con razón) a esa propuesta disciplinar por ser una estrategia subjetivista, al menos en ese caso esa posición se adopta de una forma "consciente". En cambio, otras propuestas y arqueólogos desarrollan de hecho el mismo tipo de operación subjetiva de un modo totalmente "inconsciente". Así, por ejemplo, a través de una subdisciplina como la Arqueología Ecológica, la Arqueología ha diluido el estudio de la relación naturaleza-cultura dentro de las categorías del teleologismo ecologicista, en vez de convertirse en una crónica ausente de la reconciliación entre ambas esferas. Incluso cuando se deja hablar a la Geografía, ciencia espacial y humana por definición, se tiene en ella un discurso que escribe la frontera y que así crea al "hombre de las nacionalidades", condición de posibilidad del orden burgués.

Los ejemplos de esta victoria del tiempo sobre el espacio son innúmeros. Un caso representativo de la misma lo ofrece la temporalización cotidiana de hechos de caracter espacial que desempeña la función de poner en forma de discurso ideológico circunstancias diversas de la realidad social. Nos referimos a formulaciones como la que, al percibir tres espacios distintos (una vivienda rural, un paisaje urbano y una sala de ordenadores), reconvierte esa percepción de orden estrictamente espacial en una representación de orden cronológico donde cada uno de esos espacios pasa a significar el pasado, el presente y el futuro, contribuyendo con ello a sostener la creencia ideológica en una única línea de continuidad temporal en la que el devenir adquiere un orden lógico presentando lo que tiene que desaparecer, los pasos necesarios que hay que seguir y el punto al que indudablemente se debe llegar.

También la Arqueología ha sido influida y, en parte, constreñida por las consecuencias de esta supeditación del espacio al tiempo, aún cuando el efecto de las mismas, tal y como es previsible, es especialmente visible dentro de los programas de investigación que, partiendo de la New Archaeology, se han ocupado del estudio del espacio. Así, si desde la perspectiva que hemos presentado, se revisan las aproximaciones arqueológicas al espacio, podemos apuntar que sus rasgos (y limitaciones) más características serían las siguientes:

18. Tal y como lo ilustra la revisión crítica del Discurso Histórico realizada por Bermejo (1986 y 1987), que muestra como la concepción del sujeto operada a través de Hegel, al lado de la aparición de nuevas nociones totalizadoras como "nación", "sociedad", "cultura" y "civilización", y la propia instauración del Discurso Histórico, no se pueden separar de la formación de los estados nacionales en el XIX, el predominio de la burguesía y la hegemonía del capitalismo industrial. 


\subsection{El orden del espacio}

Toda esta discusión anterior, ¿a dónde nos lleva? ¿qué nos permite pensar como arqueólogos que antes no pensáramos?

Creemos que sólo el espacio espacialmente entendido permite valorar debidamente cada contexto social específico, evitar la injusticia del Juicio Final, propiciar una recompatibilización entre naturaleza y cultura, y posibilitar una lectura materialista que no se pierda en la metafísica de un combate imaginario entre entidades ideales a través de un tiempo que no existe ${ }^{19}$.

Además de ello, es urgente acostumbrarse a ver el tipo específico de subjetivismo que está implicado en formas de operar, joh ironía!, aparentemente objetivistas y reconocer que la subjetividad no es un defecto exclusivo de la Arqueología Subjetiva de los años 80.

En beneficio de la brevedad, concretaremos en tres puntos sencillos esta revalorización cultural del espacio.

(1) En contra de la aplicación a culturas distintas de las occidentales del concepto de espacio de la modernidad blanca, se debe enfatizar que la noción según la cual la cultura es un mecanismo de enfrentamiento con la naturaleza, es un mero postulado ideológico cuando se admite que es válida para toda y cualquier sociedad o que éstas profesaban el mismo tipo de objetivo energético-productivo en su relación con aquella ${ }^{20}$.

Los posicionamientos en sentido contrario niegan (o prescinden del hecho de) que hay sociedades (normalmente las primitivas) en las cuales existió "una conciencia de la unidad de la naturaleza", y que es esa conciencia lo que nuestra cultura tiene que recuperar si es que quiere lograr un desarrollo armónico (Tricart y Kilian 1982: 281). La "interdependencia entre el hombre y la naturaleza" fue sentida en esas sociedades, fue condición de supervivencia de las mismas y es, siguiendo su ejemplo, que debemos eleiminar "el falso problema que consiste en enfrentar la naturaleza y el hombre" (1982: 8-9)

Parece, por lo tanto, que el planteamiento sobre la relación naturaleza-cultura, espacio-sociedad, debe ser exactamente el contrario del que predomina en el sistema de saber burgués: recuperar la unidad entre la naturaleza y el hombre, "reconciliar el alma y el cuerpo, la mente y la ecología, el pensamiento y el mundo" es la única forma de alcanzar "una clase de materialismo acorde con los desarrollos actuales de la ciencia" y superar así "un dualismo filosófico que arranca de Descartes y que ha trabado totalmente el pensamiento moderno" (Lévi-Strauss 1972: 46).

(2) En contra del predominio del discurso bajo coordenadas temporales, se debe argüir que es necesario en Arqueología prescindir un poco del tiempo para pensar un poco más en el espacio.

19. "Metaforizar las transformaciones del discurso por medio de un vocabulario temporal conduce necesariamente a la utilización del modelo de la conciencia individual, con su temporalidad propia. Intentar descifrarlo, por el contrario, a través de metáforas espaciales, estratégicas, permite captar con precisión los puntos en los que los discursos se transforman en, a través de y a partir de las relaciones de poder. La utilización de términos espaciales tiene un cierto aire de anti-historia para todos aquellos que confunden la historia con las viejas formas de la evolución, de la continuidad viviente, del desarrollo orgánico, del progreso de la conciencia o del proyecto de la existencia. Desde el momento en el que se hablaba en términos de espacio, se estaba contra el tiempo. Se "negaba la historia", como decían los tontos. No comprendían que la descripción espacializante de los hechos del discurso desemboca en el análisis de los efectos del poder que están ligados a ellos" (Foucault 1980b: 117-8).

20. "Lo que aquí no se reconoce (y esto equivale a un alineamiento con los principios de la economía política) es que el hombre primitivo, en sus intercambios simbólicos no se mide con la naturaleza. Este hombre no conoce la Necesidad", (Braudillard 1981: 59, comentando la obra de Sahlins Economía de la Edad de Piedra - 1977). 
Esta precaución de orden teórico será especialmente significativa en aquellos trabajos que versen sobre el espacio en su dimensión de fenómeno socio-cultural. Dentro de la Arqueología del Paisaje este punto, además, nos ofrece un útil metodológico muy rentable. Pues por debajo de la problemática relativa a la contemporaneidad o no de un conjunto de yacimientos de una zona dada, conviene percibir cuándo esta cuestión es en realidad una falsa dificultad que escamotea la posibilidad de observar regularidades espaciales ajenas en gran medida a la cronología, la periodización, la secuencia y la fase, e involucradas en cambio con la realidad discontínua, mutante, repetitiva, recurrente, de las prácticas sociales ${ }^{21}$.

Bajo estas notas heterodoxas, se trata de insistir en que tal vez sea imposible e inútil buscar órdenes temporales, de reconocer que todo orden cronológico es o bien una apariencia, o bien una abstracción que un pensamiento ajeno al contexto analizado formula en un intento moderno de comprensión. Precisamente por ello, podríamos aceptar que generar abstracciones de orden espacial de los datos arqueológicos considerados sería una forma de operación del análisis arqueológico igualmente válida, pues ellas, aunque sean tan equívocas como las reconstrucciones cronológicas, tendrán al menos el interés de ser originales, abrir nuevas perspectivas y cuestionar la voluntad de saber-poder dominante.

(3) En contra de la posible generalización de los presupuestos anteriores, en contra incluso de la propuesta de sustitución del tiempo por el espacio, se debe reconocer que este replanteamiento está interferido por las condiciones ambientales sobre las que se ha generado, en interacción constante con la práctica arqueológica y con una experiencia histórica y social concreta.

En efecto, esta alternativa no se entendería si no se aclarase que procede, entre otras cosas, de un contexto particular. En Galicia, donde intentamos desde hace algún tiempo desarrollar una línea de trabajo en Arqueología del Paisaje, disponemos de un paisaje rural y de un sistema agrario tremendamente arcaicos y conservadores, generados por la vigencia y transformación a lo largo de por lo menos doce siglos de un modo de vida campesino tradicional. El tiempo histórico de esa realidad social ha poseido una cadencia tan lenta que más que una acumulación paulatina haría pensar en una historia estacionaria ${ }^{22}$. En cualquier caso, ese paisaje campesino tradicional nos ofrece la ventaja de una situación que, dada su racionalidad antigua y correcta preservación, permite establecer analogías etnográficas fiables y contextualizadas; y nos plantea el desafío de un resultado histórico que, bajo la imagen (más aparente que real) de permanencia, incita a pensar de qué modo y con qué consecuencias, sobre una malla de poblamiento y, tal vez, unas pautas de ocupación del espacio recurrentes a través de siglos, se sobreimpondrían relaciones sociales y formaciones socio-económicas diferentes que, si bien pudieron haber mantenido un espacio formal semejante, sin embargo podrían representar paisajes dispares ${ }^{23}$.

Así, en vez de caer en la trampa de considerar ese paisaje rural como una mera analogía etnográfica, o de ver en él el reflejo de un proceso histórico del que ese paisaje actual sería heredero y de apoyarnos en esa "interpretación" para trazar una supuesta identidad del "ser gallego" con su paisaje, debemos tratarlo como un punto de llegada, como un resultado consecuencia en gran medida de

21. Una alternativa de este estilo fue ensayada en Criado 1989a.

22. Esta situación está vinculada al largo proceso histórico que ha construido en Galicia un sistema agrario tradicional, cruzado por "fuerzas de inercia, llegadas desde el fondo de los tiempos" (Bouhier 1979: 3), que aparece en su plena madurez en el siglo XVIII, que se ha conservado con especial vigor incluso a través de los momentos de descomposición de ese sistema (y que se sitúan en el primer tercio de este siglo a través de la redención de foros y en los desarrollos posteriores a la década de los 60), y que testimonia el éxito relativo de la organización campesina.

23. En la actualidad, por ejemplo, el sistema agrario tradicional en vez de desaparecer simplemente ante el frente urbano e industrial, se ha combinado con él en un profundo proceso de simbiósis que supone la coexistencia de formaciones económico-sociales opuestas (véase López-Suevos 1975). 
procesos presididos por el azar, como un mosaico generado por la superposición de patrones de ocupación del espacio, relaciones sociales y construcciones imaginarias, pero en el cual la permanencia de una misma racionalidad campesina permitiría calibrar la analogía y posibilitaría la utilización de ese espacio agrario como modelo descriptivo-interpretativo en contextos socio-económicos análogos ${ }^{24}$.

Hasta aquí no se ha pretendido más que apurar algunas consideraciones sobre los límites que el concepto de espacio burgués y la supeditación del espacio al tiempo imponen a la Arqueología del Paisaje. Esta orientación, fundamentalmente negativa, permite extraer algunas posibilidades alternativas que, en general, se pueden agrupar en dos conjuntos principales: uno de caracter metodológico y otro de caracter interpretativo. Dejaremos las primeras ${ }^{25}$ y nos centraremos en el apartado siguiente en las segundas.

\section{POSIBILIDADES: PENSAMIENTOS, PAISAJES Y SOCIEDADES}

\subsection{Las razones del espacio}

El argumento esencial de la exposición anterior, esto es, la noción de que existe una correspondencia estructural entre concepto de espacio y estrategias socio-culturales, además de ser un instrumento útil para la crítica historiográfica de la Arqueología, es también, en la medida en que establece un rasgo extrapolable a otras sociedades, un concepto rentable para el análisis cultural.

Teniendo ello presente, creemos que se puede responder la cuestión que define el punto de partida de nuestra propuesta ulterior: ¿por qué durante la mayor parte de la historia de la humanidad, la acción humana no ha transformado el entorno ${ }^{26}$ ? Esta cuestión, en realidad, oculta otros dos problemas:

(a) ¿por qué durante todo ese tiempo el hombre no alteró la morfología natural del medio a través de modificaciones sociales del mismo? y (b) ¿por qué en ese mismo tiempo no se alteró el entorno a través de construcciones humanas que lo adjetivasen culturalmente?

La dualidad de la cuestión anterior torna a ésta mucho más significativa. El primer problema se podría solventar apelando a propuestas mecanicistas o funcionalistas, alegando, por ejemplo, que la no-transformación del medio fue debida a la baja cuantia de los efectivos demográficos o a la no necesidad de alterar el medio para sobrevivir. El segundo problema, por su parte, recuerda que el monumentalismo, sea del tipo que sea, no ha existido siempre, sino que ha surgido a partir de un momento en el que su emergencia supone asímismo el inicio de la construcción cultural del entorno. Ahora bien, en la medida en que la monumentalidad connota ante todo valores de orden simbólico e ideológico ${ }^{27}$, el segundo problema, haciéndonos huir de determinismos fáciles, nos enfrenta en cambio a la dimensión cultural de la cuestión anterior.

24. Una alternativa de este estilo fue ensayada en Criado $1989 \mathrm{~b}$ y, más recientemente, en el Proyecto Bocelo-Furelos (ver los primeros resultados en esta línea en Criado et al. 1991 -en particular en su último capítulo- o también en Díaz-Fierros et al. 1992).

25. Se consideran en cambio con cierto detalle en Criado 1993a y 1993b y en diferentes capítulos del volumen de DíazFierros et al. 1992.

26. Este planteamiento depende en gran medida de los trabajos que hemos realizado sobre los inicios de la monumentalidad y sobre ẹl significado y configuración del fénomeno megalítico; a ellos nos remitimos para justificar la aproximación que aquí seguimos: Criado et al. 1986: 157 y ss., Criado 1989a y 1989 b.

27. Véase a este respecto Hodder 1984, Bradley 1993, Tilley 1993 o los trabajos del volumen 22 de World Archaeology sobre el orgien y desarrollo de la arquitectura monumental. 
Considerando ésta desde el punto de vista presentado en el apartado precedente, se intuye ${ }^{28}$ que la no transformación del medio natural por las prácticas de subsistencia de ciertas comunidades debió ser compatible con unas prácticas socio-culturales que no pretendieron diferenciarse de la naturaleza a través de construcciones artificiales. Esta circunstancia indicaría una estrecha relación estructural en las estrategias de apropiación del espacio entre pensamiento, organización social, subsistencia y concepción-utilización del ambiente. En las páginas siguientes (apartado 2.2.) presentaremos en esquema una alternativa interpretativa que, en sus consideraciones, atraviesa horizontalmente estos cuatro niveles intentando preservar siempre como principio básico la compatibilidad estructural necesaria entre todos ellos ${ }^{29}$, y examina esa relación en contextos culturales muy distintos, que cubren un abanico cronológico muy amplio. Posteriormente (apartado 3.), consideraremos el registro arqueológico gallego para, basándonos en estos planteamientos, interpretar los procesos de construcción del paisaje que, en líneas generales, se podrían haber sucedido en la Prehistoria del noroeste.

Este esquema se basa tanto en modelos antropológicos, como en datos del registro arqueológico. Debemos resaltar no obstante que la utilización de modelos antropológicos en este contexto no implica la sobreimposición a sociedades arqueológicas de meras analogías etnográficas. Sino que estos modelos son formulaciones antropológicas de caracter teórico (por lo tanto, generales y no particulares) planteadas por diversos autores como esquemas fundamentales desde los que es posible ordenar la experiencia etnográfica.

Estas formulaciones se refieren esencialmente a distintas formas posibles de racionalidad espacial, entendiendo por ello las estrategias sociales de apropiación de la naturaleza y de utilización de la misma, y asumiendo que esos dominios están en función de determinados principios culturales.

Para ello, los autores que seguiremos fundamentalmente son Cl. Lévi-Strauss y P. Clastres. Ambos han visto e interpretado características de la sociedad primitiva que otras estrategias de investigación han reducido al rango de meros epifenómenos dentro de perspectivas vulgarmente deterministas. Los pensamientos de ambos autores son compatibles entre sí y tienen además la gran utilidad de que mientras uno es una reflexión acertada sobre los hechos pertenecientes al mundo del pensamiento y de lo imaginario ${ }^{30}$, el otro es un estudio de caracter sociológico que completa al primero ${ }^{31}$. Otros autores son asímismo útiles en este sentido, especialmente para completar la doble perspectiva anterior con análisis de caracter económico ${ }^{32}$.

Teniendo en cuenta estas referencias y datos de diferente estilo, podríamos identificar cuatro actitudes principales del hombre frente a la naturaleza: pasiva, participativa, activa y destructiva. Desde nuestro punto de vista cada una de ellas habría caracterizado diferentes momentos culturales y dado lugar a cuatro grandes regularidades en la estrategia social de apropiación del espacio y de construcción del paisaje cultural. La actitud pasiva sería la vigente en la humanidad cazadora, la participativa habría caracterizado a la humanidad recolectora (que aquí denominaremos primitiva), la

28. Utilizamos esta término en el mismo sentido que Bermejo (1991) atribuye a la intuición como fundadora del conocimiento histórico.

29. El principio de "compatibilidad estructural" tiene una amplia fortuna y aplicación dentro de la teoría y de la antropología estructural; en Lévi-Strauss se puede ver, por ejemplo, en 1968: 241 y ss.; una buena aplicación de este principio utilizado para analizar el pensamiento y sus relaciones con la sociedad lo aporta Detienne 1980; en cierta medida la misma categorización se introduce dentro del concepto foucaltiano de "episteme" tal y como se encuentra en Foucault 1978.

30. Cl. Lévi-Strauss 1963, 1964, 1968, 1972, 1976 y 1986.

31. Tal y como él mismo reconoce al decir que "el estructuralismo es, como si se tratara de una teología sin dios, una sociología sin sociedad" (Clastres 1981: 170); véase además P. Clastres 1979 y 1986.

32. Sobre todo: M. Sahlins 1972 y 1977, Lizot 1977 y 1978, y T. Ingold 1980 y 1986. 
activa a la humanidad domesticadora o campesina y la destructora a la humanidad subordinada a sistemas dominados por racionalidades maximizadoras ${ }^{33}$.

\subsection{Los espacios de la razón}

\subsubsection{El paisaje ausente}

De las cuatro situaciones anteriores, sin duda la más problemática es la primera. La definición de una supuesta regularidad entre el pensamiento, la sociedad, la subsistencia y el espacio del cazador es una reconstrucción hipotética que no se fundamenta en ninguna sociedad etnográfica conocida. Unicamente se basa en la evidencia de que el paleolítico superior y el epipaleolítico habrían representado una situación relativamente distinta de la que surgirá más tarde y que se puede registrar en la experiencia etnográfica.

Esta observación no hace más que recoger la evidencia antropológica según la cual no es posible definir ni encontrar culturas originalmente primitivas ${ }^{34}$. Sería muy sencillo creer que las sociedades más "arcaicas" actuales aportan la analogía correcta de lo que fueron las sociedades de grandes cazadores paleolíticos, pero, como es bien sabido, ante tamaña presuposición caben, al menos, dos dudas legítimas. Desde un punto de vista empírico esa propuesta supone una interpretación descontextualizada que oculta circunstancias tan importantes como la existencia de condiciones glaciares o periglaciares, la subsistencia basada mayoritariamente en la caza y la no interacción entre sociedades de distinto tipo ${ }^{35}$. Y desde una perspectiva teórica implica una interpretación de caracter estatista que arrojaría a la mayor parte de las sociedades humanas fuera de la historia entendida ésta como proceso social ${ }^{36}$.

Por otra parte, los datos que poseemos del registro arqueológico nos permiten plantear hipotéticamente una regularidad cazadora cuya existencia histórica concreta habría ocupado el paleolítico fundamentalmente el superior (aunque no sabemos sí todo él, una parte del mismo ni en qué medida es anterior a él o dependió de la emergencia del Homo Sapiens sapiens) y, en parte, el epipaleolítico. Esta regularidad habría sido diferente de la que después representarán las sociedades cazadoras-recolectoras "clásicas", por más que algunos rasgos de estas sociedades primitivas o de bandas hubieran estado

33. Desde nuestro punto de vista, el valor fundamental de estos modelos y la razón que legitima su utilización, radica en que permiten pensar la Prehistoria y el registro arqueológico partiendo de formas de subjetividad que no son exclusivamente la nuestra; aunque tomadas de formas culturales que en sentido estricto no son prehistóricas, al menos tampoco son occidentales, sino que recogen patrones de racionalidad y conciencia opuestos a nuestro propio sistema de valores dominante; de esta forma la tiranía que este esquema de observación, como cualquier otro, también ejerce sobre lo observado, es menor que si partiéramos de una mera reificación de nuestras condiciones sub-objetivas. Este tema plantea una problemática muy interesante que sería necesario discutir con más detenimiento, cosa que no haremos en beneficio de la brevedad. Por la misma razón entraremos directamente en materia, dejando de lado la discusión pormenorizada de elementos complementarios que se puede encontrar en Criado 1989a y 1989b, y en Criado y Penedo 1989.

34. Véase Lévi-Strauss 1973: 91 y ss.; en este sentido es vital definir la noción de "primitivo" y concretar qué se entenderá por ella, discusión que se puede encontrar en Kuper 1988.

35. Fenómeno en cambio que es muy importante en contextos etnográficos, donde la mayor diversidad de formas socioculturales crea situaciones de interrelación muy significativas entre sociedades cazadoras-recolectores, sociedades campesinas e, incluso, altas culturas; véase Godelier 1976, Bahuchet et all. 1982 y Blackburn 1982.

36. Evidentemente la mayor parte de las sociedades humanas fueron ajenas a la Historia entendida ésta como discurso de legitimación, como forma específica de historicidad; esta precisión, que permitiría aclarar las malinterpretaciones respecto a la oposición entre Estructuralismo e Historia, nos lleva a un tema distinto que no se debe confundir con la presente formulación. 
contenidos en esa situación prehistórica. Se pueden sostener ambas afirmaciones basándose en la evidencia documental aportada por la subsistencia y el arte de esos momentos. En ambos campos destaca la tremenda especificidad del paleolítico respecto a situaciones posteriores. En el primero nos encontramos ante una caza de tipo aleatorio, opuesta a la selectiva de contextos epipaleolíticos (Mithen 1987 y 1988), que subraya la existencia de una subsistencia más o menos oportunista, caracterizada por la precariedad de la economía y por una racionalidad económica dirigida a la reproducción simple.

Para el propósito de este trabajo es más significativa la profunda coherencia que se percibe entre la práctica de ese régimen de subsistencia y la práctica de un ejercicio artístico concreto. Tal y como hemos argumentado en otro punto (Criado y Penedo 1989, aunque desde otros puntos de vista, también incide en ello Mithen 1990), creemos que en ambos códigos culturales la sociedad y el individuo son entendidos como entidades que no desarrollan una acción distinta e independiente de la naturaleza. Un tipo de arte que no habla del hombre, que sólo habla de la naturaleza y que, además, como tal discurso cultural sin embargo se oculta y esconde en la cueva, no indica sólo que la sociedad pertenezca al orden de la naturaleza sino que, desde nuestro punto de vista, supone que ni tan siquiera se plantea esa reflexión, pues hacerlo habría supuesto introducir la duda sobre si la cultura es algo distinto o no a la naturaleza. La invisibilidad paradójica de ese arte, es coherente entonces con la fragilidad de la Cultura Material existente en ese contexto y con la futilidad de su registro arqueológico.

Esta actitud cultural se corresponde con una forma de subsistencia que, tal vez como consecuencia de la baja escala de las capturas paleolíticas, no alteró el entorno ni precisó generar medidas de orden social para evitar la alteración del medio, (del estilo de estrategias de caza selectiva). En cualquier caso muestra la plena compatibilidad entre el orden natural y el cultura, de tal modo que, de hecho, no se puede decir que exista una estaretagia social consciente de apropiación de la Naturaleza. Por esta razón, y no por ningún tipo de posición etnocentrista que viése el signo de un progreso teleológico en el aumento progresivo de la acción humana sobre el entorno, se puede caracterizar la actitud sociocultural cazadora como pasiva frente a la naturaleza. Por eso mismo creemos que se puede hablar de un paisaje ausente.

Recientemente se ha planteado que la capacidad de elaboración de adornos personales, fundamentada en el progreso de las técnicas de representación y manipulación de imágenes, significó un progreso de la abstracción y de la capacidad de aislar atributos y de transferirlos de un contexto a otro (White 1989). Este progreso, según ese autor, habría sido la base del ingente desarrollo del arte y las técnicas, del despegue cultural en suma, durante el Paleolítico Superior. No nos interesa ahora la significación social que el autor descubre trás este fenómeno ${ }^{37}$. Debemos, en cambio, constatar que el orden cultural paleolítico, la regularidad cazadora, no surgió de la nada sino que fue generado por un proceso de desarrollo histórico que se prolongó durante varios milenios, y resaltar además que esa capacidad de abstraer atributos e intercambiarlos entre códigos se realiza (de acuerdo con los datos

37. Esta interpretación, desde nuestro punto de vista, plantea serios inconvenientes. Singularmente, cuando el autor intenta vincular las técnicas de adorno con la representación de categorías sociales y de identidades individuales, argüyendo que es en el Auriñaciense cuando por primera vez aparecen institucionalizadas las diferencias de posición social, está, desde nuestro punto de vista, recogiendo la estrategia hedonista típica de los años 80 que concibió el propio cuerpo como el escaparate visible de la socialización. Desde un punto de vista teórico, además, se debe argüir que, aunque el autor pretende hacer algo así como un trabajo de arqueología estructural, en realidad su artículo es un buen ejemplo de lo que es un estructuralismo entendido a nivel metafórico, versión frecuente y engañosa que agota las posibilidades más ricas contenidas en esta propuesta teórica. 
que ese mismo autor considera) a partir de una reflexión sobre y dentro de la naturaleza, ya que se basa en reflexiones sobre elementos naturales que se extrapolan por analogía entre ámbitos diferentes. De este modo, el hecho de que la condición básica del conocimiento sea su compatibilidad con el orden natural, representa en todos sus sentidos la estrecha identificación entre las prácticas sociales y la naturaleza.

Con esta última consideración nos aproximamos al "pensamiento totémico", a la lógica de las cualidades concretas y a las posiciones que considera Lévi-Strauss (1964). Sin embargo la diferencia esencial que nosotros creemos observar entre este presunto Pensamiento Cazador y el Pensamiento Salvaje, radica en la finalidad de la acción humana, ya que mientras en éste la intención del proceso de identicación cultural con la naturaleza es involucrar a la sociedad como realidad distinta pero participativa de aquella, en la regularidad cazadora la intención que hipotéticamente se percibe sería significar la equiparación absoluta entre cultura y naturaleza, de tal modo que la actitud de la primera hacia la segunda sólo puede ser pasiva. A pesar de que la distancia aparente entre una y otra posición anima a situar aquí la discontinuidad entre dos regularidades distintas, la semejanza entre ambas y, sobre todo, entre sus resultados ${ }^{38}$, pudieran avalar la hipótesis de que en realidad la actidud cazadora constituye la prehistoria del Pensamiento Salvaje, situación que define a un tipo de sociedades de existencia histórica concreta que se pueden definir como primitivas (en el sentido de Clastres 1981) ${ }^{39}$.

\subsubsection{La naturalización del paisaje}

De este modo se presenta una situación diferente en la que el pensamiento y la sociedad conceptualizan de forma distinta su relación con el espacio y emerge, entonces, un nuevo tipo de paisaje social. Este paisaje se puede definir como correspondiente a la regularidad primitiva. Con ello nos referimos a una situación que históricamente se correspondería con sociedades mesolíticas y neolíticas y que, si bien desde el punto de vista de la subsistencia se ha identificado sobre todo con los grupos cazadores-recolectores, habría que superar esta perspectiva estrecha e introducir dentro de ella a las primeras sociedades agrícolas y, en general, a todas las comunidades con una agricultura no perma-

38. En el sentido que aquí se argumenta, son muy significativos y se podría llegar a comprender los datos aparentemente anómalos que remontan cada vez más la domesticación de plantas y animales en diferentes zonas del globo; piénsese en la antigüedad argüida por el equipo de J-Golson para la adopción del cultivo en Papua-Nueva Guinea, o en los datos sobre la manipulación quasi-doméstica del caballo y el perro durante el Paleolítico superior. Desde nuestro punto de vista estos datos corroboran la lectura que se plantea en los dos siguientes apartados: si la neolitización sólo es conceptualmente posible dentro de las coordenadas del Pensamiento Salvaje, ésta deja de ser un acontecimiento privativo de momentos crono-culturales avanzados y, sencillamente, podrá ser casi tan antigüa como sea aquél.

39. La historización que aquí se propone de la noción de pensamiento salvaje tomada de Lévi-Strauss requiere ciertas aclaraciones. Pues si bien es cierto que esa noción puede y necesita ser, desde nuestro punto de vista, historiada, no es menos cierto que la formulación original de Lévi-Strauss no se refiere a una realidad histórica, sino a una forma de pensar o, mejor, de razonar que aparecería en contextos plurales, independientemente de su cronología y coordenadas sociales. En este sentido existe una ambiguedad en castellano que se podría aclarar traduciendo el término penseè utilizado por Lévi-Strauss por razón, mientras el castellano pensamiento equivaldría al francés pensée, (consideraciones más detenidas en este sentido se pueden encontrar en Dan Sperber 1985 y U. Eco 1968). Utilizando esta ambiguedad, y a los efectos de esta propuesta, nosotros diferenciaremos una razón salvaje, entendida en sentido lévi-strausiano como estructura o sintáxis sobre la que se articula el pensamiento, de un pensamiento salvaje, entendido como la contextualización histórica y social de esa razón, como una sintáxis complementada con un repertorio semántico concreto; mientras lo primero nos permite prever cómo habría funcionado el pensamiento de las sociedades que no podemos observar, lo segundo nos permite reconstruir cómo se habría adaptado ese pensamiento a condiciones sociales específicas y de qué modo se habría compatibilizado con una organización social, subsistencia y concepción del espacio determinadas. 
nente, de roza y azada, o practicada en huertos reducidos con una dedicación semejante a la que se confiere al cuidado de jardines silvestres.

A pesar de la aparente (y tradicional) diferenciación entre ambos tipos de subsistencia, su estrecha compatibilidad con el orden natural y la presencia en una y otra de pautas de subsistencia, asentamiento y territorialidad definidas por su no permanencia, constituyen rasgos comunes que contribuyen a equiparar ambas situaciones. Lo importante no es la técnica, sino las relaciones sociales de producción, las relaciones con los medios de la misma y, en concreto, la forma de apropiación de la tierra.

De este modo, en el seno de esta regularidad común se inscribe un nuevo tipo de subsistencia que, basada en la íntima comunión entre naturaleza y cultura, funde las prácticas de obtención de bienes con la racionalidad propia del entorno ecológico dando lugar a un tipo de aprehensión del espacio en el que la acción humana solo promueve excepcionalmente un impacto directo sobre éste. De este modo, el tipo de prácticas, el ritmo de las mismas y su efecto destructivo, se amoldan al equilibrio natural y surgen formas diversificadas de subsistencia recolectora, periodicidades de orden estacional y estrategias de especialización y selección que mitigan y diluyen el impacto destructivo de la acción social. Todo ello no haría más que actualizar el principio rector fundamental de esta situación: el hecho de que la reproducción del grupo social queda supeditada a la reproducción natural del espacio físico, de que la condición básica de la primera es, en definitiva, el mantenimiento de la segunda sin producir sobre ella alteraciones significativas.

Este proceso conducirá a que las sociedades humanas empiecen a desarrollar labores de transformación efectiva del entorno. Pero este proceso hará que esa transformación no se haga apenas visible porque, de hecho, el primer efecto que el hombre ejerció sobre el medio no fue para someterlo a un cambio de naturaleza, sino para contribuir a la correcta preservación de la naturaleza. En este sentido se deben entender prácticas verificadas en el registro antropológico, arqueológico e, incluso, paleoecológico: incendios provocados para eliminar el exceso de vegetación en medios boscosos o propiciar el resurgimiento de praderas naturales, utilización de estrategias de caza selectivas, realización de sistemas de corrales y trampas para incrementar el control de la caza o, incluso, cuidado meticuloso de plantas que crecen de forma silvestre... De esta forma, la primera acción humana sobre el entorno estuvo presidida por una racionalidad conservacionista; podemos definir este tipo de actitud cultural ante la naturaleza como participativa. Esta actitud es coherente con la racionalidad productiva de unas estrategias de subsistencia que cada vez están menos enfocadas hacia la reproducción simple, y más hacia los rendimientos aplazados o diferidos. En ellas las insuficiencias de la economía ya no se cubren exclusivamente con el hiperdesarrollo de las relaciones de reciprocidad, sino con la extensión de éstas hacia relaciones de redistribución (Bate 1986) y, sobre todo, con la identificación entre racionalidad productiva y racionalidad cultural.

En este punto se hace urgente cambiar totalmente la concepción tradicional y childeana sobre la neolitización ${ }^{40}$. Sería necesario dejar de entender el neolítico como un fenómeno innovador significado por la aparición de una nueva racionalidad económica, basada en la producción, en la domesticación del entorno y en prácticas subsistenciales fundadas en la manipulación y alteración del medio. En vez de ello, habría que reconocer lo que en Antropología ya hace tiempo que se reconoce (LéviStrauss 1963), y lo que las revisiones arqueológicas recientes de las sociedades epipaleolíticas y de los procesos de neolitización empiezan a mostrar: existe una amplio grado de indeterminación entre los primeros agricultores y los últimos recolectores. Es más, la supuesta diferencia entre ambos, en vez de

40. Para completar la discusión siguiente se puede consultar la revisión sobre las teorías e interpretaciones arqueológicas de la Neolitización realizada en Hernando (1993). 
responder a un proceso de transformación o evolución social, se corresponde con un umbral ambigüo que se cruza repetidamente hacia adelante y hacia atrás: grupos recolectores se vuelven agricultores y grupos agricultores retornan a la recolección, indicando de este modo que agricultura y recolección son dos fórmulas estratégicas posibles de una misma racionalidad cultural que, como tales, son intercambiables y se pueden adoptar coyuntural y episódicamente.

Desde nuestro punto de vista, lo que aquí se percibe es que debajo de ambas estrategias de subsistencia y del aparente cambio revolucionario de una a otra, existe una continuidad manifestada por la presencia de una misma racionalidad económica, por la existencia de una misma y única forma de entender la relación de la sociedad con el medio. Esa racionalidad es la que traduce el Pensamiento Salvaje, dentro del cual se encuentran la sintáxis (o funciones mentales: interrelación significativa entre la sociedad y el mundo, lógica de las cualidades concretas, observación de lo inmediato, reflexión desarrollada metafóricamente y encadenación paradigmática de esas reflexiones) y la semánti$c a$ (en concreto una determinada conceptualización del tiempo, el espacio y la relación entre sociedad y naturaleza), que hacen factible una determinada construcción social de la realidad. Ese patrón de racionalidad hace que el neolítico, en vez de ser entendido como domesticación de la naturaleza, debiera ser entendido como naturalización de la cultura.

Esta noción de neolítico no sólo es opuesta a la tradicional, sino que también se opone a ciertas conceptualizaciones recientes que, después de diferenciar entre el neolítico como economía y el neolítico como forma de pensamiento, retrasan el neolítico económico real hasta finales de la Edad del Bronce (al menos en el mundo atlántico), mientras mantienen la aparición del modo neolítico de pensar entre los IV y III milenios a.C., identificándolo con una "forma de vida que separa lo humano de lo natural" (Thomas 1991: 181; ver también Hodder 1990). Creemos que en estos casos se desliza una ambigüedad motivada por la resistencia a desechar el concepto de Neolítico o a alterarlo profundamente. Dentro del Neolítico se han entremezclado dos cosas fundamentalmente distintas: la posibilidad de interferir activamente sobre plantas y animales, y los procesos sociales generados presuntamente como consecuencia de esa posibilidad. Ahora bien, aunque es cierto a la luz de los resultados producidos por esos procesos (alteración del medio, maximización economo-energética...), que éstos están orientados por una lógica que separa lo humano y lo natural, en cambio, desde nuestra perspectiva, la posibilidad de interactuar activamente con otros seres vivos no es consecuencia de esa separación, sino de una lógica que, antes bien, identifica lo humano con lo natural.

Si siguiendo a T. Ingold (1980) asumimos que el neolítico supone ante todo la aparición de nuevas relaciones sociales de producción que representan una forma específica de apropiación del espacio, caracterizada por el surgimiento de nuevas relaciones de control y dominación de la naturaleza (plantas y animales) y, correlativamente, de nuevas formas de integración de ésta dentro de la realidad social, y aceptamos después que estas formas adoptan plenamente una racionalidad salvaje, entonces la presunta novedad del neolítico se desvanece y esta fase, en vez de abrir una nueva época (la de la Humanidad protohistórica e histórica), sería el episodio que cierra la época anterior (la de la Humanidad Paleo y Epipaleolítica).

Dentro de esta situación, que coloca bajo una misma regularidad a sociedades cazadoras-recolectoras y agrícolas incipientes, dotadas de un patrón de subsistencia y asentamiento móvil, basadas en la utilización de recursos móviles y que no están fijados a un espacio específico, se establece una forma de apropiación de la naturaleza que, coherentemente con los valores que se han comentado, se limita a la apropiación simbólica o ritual de ésta. Según T. Ingold (1986), este proceso cultural se efectúa a través de la demarcación simbólica de lugares puntuales, normalmente mojones o signos naturales señeros en el paisaje (tales como rocas, afloraciones, espacios o puntos naturales cuyo privilegio y 
especificidad está en estrecha relación con sus características e impacto visual), y de líneas de movimiento a través del espacio que, estando prefiguradas por la topografía, son utilizadas comúnmente por los animales salvajes y apropiadas por el hombre para sus propios desplazamientos ${ }^{41}$. El objetivo de este tipo de semantización cultural del espacio se enfoca hacia el control provisional de áreas especiales de recursos: zonas óptimas de caza, abrevaderos, campamentos... (Ingold 1986: 135 y ss). En esta situación el conjunto del paisaje sigue siendo ante todo un espacio abierto, en el que no se introducen ni barreras sociales físicas ni, en definitiva, un patrón de territorialidad (en sentido estricto) permanente y estable. En relación con ello, la apropiación social del espacio se realiza en forma de deambulación a través de la superficie del terreno y de dominio visual de esos terrenos desde puntos concretos. Esta forma de ocupación y semantización del espacio es semejante al sistema de configuración territorial que se encuentra en algunos animales como, por ejemplo, los lobos: entre ellos la aprehensión del territorio se realiza con base en puntos de significación funcional específica (áreas de descanso, campamentos, cazaderos, abrevaderos) y en las líneas de desplazamiento que los unen entre sí; estas líneas adoptan, generalmente, un patrón tendente a la espiral, con lo que se incrementa la permeabilidad entre el territorio animal deambulado y el espacio propiamente dicho (Grande del Brío 1982) ${ }^{42}$.

Las nuevas concepciones espaciales se concretan en la emergencia de una representación artística visible y de elementos que podemos definir como monumentos salvajes. Esta noción, explicada en Criado 1993b, se refiere al tipo de utilización social de accidentes naturales ejemplificada por R. Bradley (1993: 26 y ss.).

Esta racionalidad espacial, que da lugar a un determinado paisaje imaginario y se redobla en un concreto paisaje social, es plenamente compatible con un tipo específico de sociedad. Esa sociedad, que a veces se ha definido debajo de las definiciones abstractas de tribu segmentaria (Sahlins 1972 y 1977) o comunidad primitiva tribal (Bate 1986 y 1989), se puede caracterizar mejor (utilizando las formulaciones de Clastres) como una sociedad indivisa, significando con ello no tanto que no existan divisiones o desigualdades dentro del ser social, sino que no existen ámbitos de especialización divididos, separados, del resto de la sociedad. Este principio general se aplica tanto a la esfera del poder como a otras circunstancias. No existe, por ejemplo, una economía dividida, un área específica de lo económico separada del conjunto de la sociedad ${ }^{43}$.

\subsubsection{La domesticación del paisaje}

En cambio, lo que tradicionalmente se ha entendido como la auténtica revolución neolítica, (esto es, la ruptura irreversible entre lo humano y lo natural, la plena domesticación del mundo), habría llegado más tarde. Surgió no con el mero inicio de la agricultura, sino con la generación de formas agrícolas específicas, entre las que destacan sobre todo la agricultura permanente y las prácticas agrícolas que requieren del concurso de considerables inversiones en trabajo y en medios técnicos (irrigación, abonado...) y, en general, con las prácticas subsistenciales que implican una apropiación

41. Estas mismas ideas han sido utilizadas recientemente por R. Bradley con notable acierto para definir el tipo de espacio simbólico vinculado con el arte protohistórico (Bradley 1991 y 1993: cap. 2).

42. Tal y como veremos posteriormente, esta coincidencia (que nos hizo notar nuestro compañero $F$. Infante) ofrece un instrumento analítico de primer orden, (véase la nota 57 más abajo).

43. Aquí radica la dificultad esencial del estudio de la economía primitiva: no es posible estudiarla sin estudiar asímismo la sociedad, pues las relaciones de producción son ante todo relaciones sociales y después económicas, como plantea Godelier 1976. La economía primitiva se caracteriza por poseer una racionalidad autárquica, concebida en función de la corta duración, por no generar excedentes, no poseer el concepto de "producción" y no trabajar más de la cuenta o tener superávit de trabajo (Lizot 1977). 
plena de la naturaleza sin que forzosamente tengan que ser sociedades agrícolas. Este proceso en unos casos se habría dado de forma inintencional, como una consecuencia no deseada de los desarrollos y modificaciones incipientes propiciados por la situación anterior. En otros habría respondido sobre todo a la intención por parte de ciertos sectores sociales de rentabilizar y maximizar las nuevas potencialidades humanas y culturales puestas ahora en juego. De esta forma ese proceso habría conducido al modo de vida campesino y a los contextos de cambio representados en la transición del Neolítico tardío al Calcolítico-Bronce, tal y como ha sido estudiado en Vicent (1990).

Aunque el concepto de campesinado necesita ser aclarado en cada caso ${ }^{44}$, esta situación se puede definir mejor aplicándole esa término. Según E. Wolf indica sobre todo la presencia de poblaciones dependientes cuya subsistencia se basa en la agricultura (1982). T. Shanin, de modo complementario, define a los campesinos como pequeños productores que con la ayuda de una tecnología sencilla y del trabajo de sus propias familias producen para su propio consumo y para pagar las rentas que deben a los detentadores del poder político y económico (1987: 5 y ss.).

Este último rasgo, aunque para llegar a él se establezcan diferentes situaciones intermedias, es especialmente importante, ya que subraya la correspondencia entre el modo de vida campesino y la presencia y desarrollo de estructuras de desigualdad, competición (entre grupos o individuos) o coerción social. De este modo, la constitución del campesinado representa la descomposición del modo de vida primitivo y el surgimiento de la sociedad dividida. En este contexto, lo que Clastres denomina división social se refiere no sólo a la aparición de ámbitos autónomos de control y ejercicio del poder, sino también de esferas especializadas de realización y división social del trabajo, esto es, de lo que se da en llamar especialización social: producción, defensa, ritual...

Recientemente T. Shanin ha completado la caracterización del campesinado insistiendo en que el modo de vida campesino reporta una determinada estructura ocupacional, la presencia de granjas familiares como unidad básica de la interacción social y la existencia de una relación específica con la tierra (Shanin 1990: 23-7).

Esta última circunstancia es esencialmente importante en nuestro caso. Implica que el surgimiento del campesinado está íntimamente unido a un tipo específico de racionalidad espacial. Con el campesino aparece un paisaje social que se caracteriza fundamentalmente por reflejar el efecto del hombre. Es más, el campesino, a diferencia de otros seres humanos históricos, precisa modelar la naturaleza de acuerdo con una morfología cultural; para él la naturaleza es una enemiga, o al menos un factor imprevisible, que debe ser domesticado. La situación campesina representa una actitud activa en su relación con el espacio natural. Por esta razón se puede definir como domesticadora. Esta situación se establecería en las sociedades arqueológicas posteriores al Neolítico Medio: Calcolítico, Bronce o Hierro, según las zonas.

Esta actitud no aparece porque sí. Está relacionada con el desarrollo de una racionalidad económica enfocada hacia la reproducción ampliada y la generación de excedentes, ya sea para satisfacer el pago de tributos o para sostener procesos de acumulación. En este tipo de sociedades, la situación salvaje antes considerada se invierte totalmente. En ellas se ha roto el equilibrio entre la racionalidad productiva y el orden natural. Pero además este tipo de sociedades necesitan realizar una expropiación permanente de los medios de producción y, esencialmente, de la tierra. Así, el patrón de apropiación de la

44. La problemática implícita debajo de esta realidad social y en las categorías utilizadas para conceptualizarla, tanto en la investigación como en la práctica política, han sido puestas de manifiesto, entre otros, por Duvignaud (1974a: 297-301 o el primer capítulo de 1977). Aunque no podemos detenernos ahora en esta problemática, conviene advertir que el campesinado no es un tipo de sociedad, sino una categoría que define una situación que reaparece en muchos tipos distintos; (sobre la noción olvidada por las modas de "tipo de sociedad" ver Duvignaud 1974b: 316 y ss.) 
naturaleza se presenta en forma de una reclamación efectiva de los derechos sobre la tierra: lo que se reserva ya no son puntos o líneas, sino superficies y terrenos que definen un espacio cerrado. El paisaje abierto anterior es sustituido por un paisaje dividido, que refleja la domesticación progresiva de la naturaleza. Como dice T. Ingold, en esta situación el paisaje se ha convertido en territorio.

En lo sucesivo, para evitar confusiones con el término Neolítico (que en el marco de este trabajo es entendido como naturalización de lo doméstico y no como domesticación de la naturaleza y, por lo tanto, equiparado con la situación salvaje o primitiva comentada en el apartado anterior), para referirnos a lo neolítico en el sentido arqueológico convencional, utilizaremos el término doméstico y sus derivados, aún cuando esta licencia tampoco evita totalmente los problemas conceptuales.

Ahora bien, la racionalidad que subyace a las transformaciones anteriores permite que, superando las equiparaciones tradicionales entre depredación y recolección y domesticación y agricultura, grupos recolectores pre-agrícolas deban ser entendidos como sociedades domésticadoras y denominados, analógicamente, "campesinos". En esta aplicación laxa del término, su sentido no viene dado por cultivar o no la tierra, sino por poseer una relación especial con ella caracterizada por la apropiación permanente de la misma y por la necesidad imperiosa de excluir a otras sociedades o grupos de su disfrute. En este sentido, el establecimiento del modo de vida campesino significa la adopción de unas estrategias de subsistencia dependientes del territorio y, complementariamente, la incorporación de valores culturales de carácter doméstico. La campesinización o domesticación entendida de este modo no está en función de condiciones o cambios tecnológicos, sino de una nueva actitud social que extiende la cultura sobre la naturaleza y convierte el entorno en campo. En esta situación se encuentran tanto grupos de base pastoríl y/o agrícola, como de base recolectora y móvil ${ }^{45}$.

Toda esta situación es coherente con el hecho de que, a difererencia de las formas de obtención de alimento de los grupos paleo-mesolíticos, que no ejercieron ninguna agresión sobre el entorno que alterase de forma irreversible el medio, entre sociedades campesinas y, en coordenadas arqueológicas, a partir de los momentos intermedios o finales del Neolítico, se encuentra un tipo de racionalidad socio-económica que demanda la alteración progresiva de la naturaleza. El efecto más claro de ello se refleja en el hecho de que, a partir de estos momentos, en el registro paleoecológico se representa cada vez más y mejor la humanización del entorno y, en cambio, se oscurecen las transformaciones debidas a alteraciones climáticas y meramente ambientales.

Paralelamente, en el seno de este pensamiento doméstico y domesticado ${ }^{46}$, aparecen nuevas concepciones de tiempo y espacio. En ellas lo que ahora se refleja es el papel activo del hombre como amo del mundo. Esta actitud hará que, paulatinamente, se vayan engendrando recursos culturales para extender y ampliar la dominación sobre el medio. Pero en cualquier caso, la sociedad y el hombre son los protagonistas a partir de ahora de una acción que modela el medio, altera el entorno natural y lo

45. En esta situación se encontrarían grupos cazadores-recolectores especializados o complejos como las comunidades de la costa oeste de Canada, o los Saamis (Olsen 1987 y 1988) e Iroqueses de época histórica, que, a pesar de vivir de la explotación de recursos silvestres, han adoptado una racionalidad productiva o maximizadora que los aproxima más a sociedades jerarquizadas y complejas que a las comunidades recolectoras tradicionales (véase en general Ingold 1980).

46. Aunque contraponemos estos términos al Pensamiento Salvaje, urge aclarar que no se utilizan en el mismo sentido que Lévi-Strauss 1964 o Goody 1985; queda aquí abierto un campo de análisis que será abordado en el futuro. Las propuestas de Goody, en concreto, apuntan a que las transformaciones en el pensamiento salvaje fueron determinadas por el abandono de la oralidad y la adopción de la escritura. Esta tésis, defendida por J. Goody en diferentes trabajos (1975, 1985 y 1987), aún no ha sido incorporada dentro de la Arqueología y, aunque recientemente ha sido cuestionada su validez, habría que tenerla en cuenta para valorar que la mayor parte de la Cultura Material que estudiamos los prehistoriadores en realidad es producida por sociedades orales y que, por lo tanto, su ejecución habría estado determinada por la economía interna y racionalidad propia de la oralidad. 
sustituye por un paisaje artificial. Poniendo las cosas en estos términos, parecería que los inicios de la vida campesina suenan parecidos a los orígenes de la modernidad. Pero esta concordancia, en realidad, sólo indica que la campesinización representa la constitución, como diría J. Vicent, del "campesinado como el zócalo inmóvil sobre el que se construye la historia". Sería el despuntar de una situación que no parará de desarrollarse en lo sucesivo dando lugar a circunstancias totalmente inéditas dentro de la historia de la Humanidad. Uno de sus puntos comunes lo representaría la aceleración del tiempo histórico que así se inicia y que contrasta con la aparente inmovilidad, que no estatismo, de la historia anterior.

De este modo, las diferencias entre un paisaje abierto e indiviso y un paisaje cerrado y dividido, la transición de un espacio generado por la indivisión al espacio construido por la división, podemos hipotetizar que se concretaron, ante todo, en la sustitución de un espacio natural y homogéneo por un espacio fragmentado y plural. Este paisaje habla no sólo del ser humano y de la sociedad, no sólo de las diferencias entre éstos y la naturaleza, sino sobre todo de las desigualdades, no naturales aunque naturalizadas, que existen a partir de ahora entre los seres.humanos y dentro de las sociedades. Estas desigualdades, que pueden ser de tipos muy distintos, se caracterizan básicamente por la expropiación de trabajo a la que dan lugar, necesaria para sostener el desarrollo productivo y los procesos de acumulación. Se concretarán en el incremento de la jerarquización y la explotación, en el surgimiento de jefaturas y sociedades estatales.

En la actualidad es un tema de discusión decidir cuándo se establece esta nueva situación. Los debates más recientes oscilan entre plantear que se adopta ex origine en el Neolítico o, como proponen diferentes autores, que se llega a ella únicamente en plena Edad del Hierro, cuando aparecen asentamientos fortificados permanentes, sistemas de parcelación del campo y evidencias indiscutibles de la existencia de agricultura intensiva. En la Europa atlántica esta última situación preludia y contiene ya todos los elementos que después se seguirán desarrollando durante época romana y medieval, tal y como en su momento avanzaba la tésis de L. White (1973). Nosotros, por nuestra parte, creemos que este problema está en realidad mal planteado.

Las evidencias que parecen indicar un acaecimiento tardío de esta situación vienen dadas por el escaso efecto sobre el medio de las sociedades anteriores a la Edad del Hierro (tal y como se traduce en los análisis paleoambientales), por la presencia de una dieta en la que aún habrían ocupado un lugar destacado los recursos silvestres (caza, pesca y recolección), y por la ausencia de datos inequívocos sobre la presencia de asentamientos humanos (circunstancia que lleva a plantear que éstos eran de carácter no permanente y que, por lo tanto, las comunidades de esos momentos seguían manteniendo un componente móvil muy fuerte); así ha sido argüido para las Islas Británicas por R. Bradley 1991b o Thomas 1991.

Estas circunstancias indicarían que la subsistencia plenamente agrícola o productora fue excepcional hasta momentos tardíos, y que durante todo el Neolítico y buena parte del Bronce se mantuvieron sociedades con características móviles, cazadoras-recolectoras y en las que, por lo tanto, parece que el tipo de apropiación de la naturaleza habría seguido encardinada dentro del marco anterior. Según R. Bradley (1993), siguiendo a Ingold, esto supondría el predominio de una geografía de lugares, caminos y vías de desplazamiento, semejante a la que describíamos para la situación anterior. Este autor, además, propone que el primer acto de neolitización en la Europa atlántica habría sido la construcción de monumentos megalíticos que, de este modo, habrían preparado el pleno neolítico económico (1993: 16 y ss.). Para subrayar esta interpretación, el mismo autor señala que la primera arquitectura monumental europea antecede a la generalización de la producción agrícola. En el mismo sentido apuntarían los monumentos levantados por grupos recolectores pre-agrícolas en la Prehistoria norteamericana y entre aborígenes australianos (idem 9-12). 
Sin embargo, al insistir en el divorcio entre la primera monumentalidad y la economía neolítica (como sugiere R. Bradley), o en la constitución del modo de vida "doméstico" en momentos tardíos de la Protohistoria (como plantea Hodder 1990 o Thomas 1991), se desliza una ambiguiedad importante. Esta ambigüedad se refiere al hecho ya no de que los monumentos establezcan las condiciones de la domesticación económica, sino de que ellos mismos son sólo posibles si previamente se ha establecido un nuevo sistema imaginario que, en el sentido aquí postulado, se puede definir como campesino.

$\mathrm{O}$ dicho de otro modo, cuando se destacan las líneas de continuidad y relación entre los grupos neolíticos que-no-son-neolíticos (Thomas 1991), los monumentos entendidos como "lugares" (Bradley 1993), o los yacimientos del Bronce dotados de una subsistencia en parte pre-agrícola y de un patrón de asentamiento itinerante ${ }^{47}$, con los grupos móviles de características próximas a las sociedades de cazadores-recolectores, se corre el peligro de escamotear el hecho de que en todos ellos se ha asentado una fórmula novedosa de relación con el espacio caracterizada por la plena domesticación de la naturaleza.

Así, aunque la racionalidad productiva "doméstica" no se establezca hasta el Hierro con todas sus consecuencias, no por ello hay que suponer que hasta ese momento se extendió como un continuum la racionalidad "salvaje". Esto quiere decir, sencillamente, que no existe relación directa entre el sistema simbólico-cultural de apropiación de la naturaleza y las prácticas de subsistencia. Antes bien, puede haber ocurrido que el cambio del primero sirva de hecho para propiciar el cambio de lo segundo ${ }^{48} \mathrm{o}$, lo que es lo mismo, que la domesticación del pensamiento sea anterior e, incluso, condición infraestructural básica de la domesticación de la economía. Si no fuera así, teniendo en cuenta los datos cada vez más abundantes que enfatizan el papel del aprovechamiento de recursos silvestres hasta épocas históricas recientes, habría que postular que la situación salvaje, pre-neolítica en sentido convencional, se extendería de hecho hasta la plena Edad Media ${ }^{49}$.

Por otra parte, creemos que no es muy significativa la ausencia de datos sobre economía neolítica antes de la construcción de monumentos megalíticos ya que, si aceptamos que en esa situación habría estado vigente el tipo de racionalidad salvaje descrita más arriba, entonces debemos aceptar que esa misma racionalidad habría determinado la invisibilidad de las estrategias económicas.

La consecuencia de las observaciones anteriores es que, en los primeros momentos del paisaje domesticado, éste se concreta en elementos de carácter simbólico-ritual que expresan la presencia de una nueva forma de construir el espacio social y entender las relaciones con éste; en cambio, la domesticación del modo de vida, el proceso que conducirá a la "campesinización" de la economía y la sociedad, sólo se establecerá de una forma paulatina. En este contexto, dentro del espacio humano aparecen elementos nuevos y viejos. Lo viejo vendrá dado fundamentalmente por el mantenimiento de formas de apropiación del espacio propias de situaciones anteriores, particularmente la configuración del paisaje a partir de una geografía de lugares y de la movilidad propia de los paisajes salvajes. Lo nuevo, por su parte, radicará en la expresión de esa geografía a través de formas monumentales plenas y de monumentos ambigüos ${ }^{50}$. (1986)

47. A este respecto véase la polémica entre M.L. Ruíz-Gálvez (1989) y S. O. Jorge (1990) sobre la obra de ésta última

48. Esta propuesta, desarrollada a partir del hecho obvio de que, dentro de un "materialismo de lo incorpóreo", todo nuevo acontecimiento social debe ser posibilitado por el pensamiento de ese grupo social, fue adelantada en Criado 1988 y $1989 b$.

49. Véase a este respecto la obra de V. Fumagalli (1989).

50. Véase sobre esta noción Criado 1993. 
En efecto, la nueva forma de construcción del paisaje fue paralela de la aparición de las primeras construcciones artificiales y monumentales sobre el espacio. Estas obras, independientemente de que sean funerarias (megalitos), fuertes, fortificaciones o palacios, son en cualquier caso construcciones humanas que, concebidas para ser vistas en el espacio y perdurar en el tiempo, adjetivan culturalmente el entorno y configuran con su presencia un paisaje socio-cultural que habla del hombre y de la sociedad ${ }^{51}$. De esta forma parecen el contrapunto cultural de la domesticación económica del medio y de la división social y, contemplado desde nuestra perspectiva, surgen como la metáfora de una nueva estrategia de apropiación del espacio.

Tal y como hemos defendido en otros puntos (Criado 1989a), los rasgos de la primera arquitectura monumental, particularmente su visibilidad espacio-temporal, indican que la emergencia de este fenómeno inédito en la historia de la humanidad, no sólo estuvo relacionada, sino que además representó la presencia de un nuevo tipo de racionalidad espacial. La nueva actitud hacia el espacio que expresan los monumentos genera, a la postre, la construcción de nuevos tipos de paisajes sociales.

De este modo, aunque un megalito sea un punto humano aislado en medio de un espacio silvestre, su mera presencia impone un sentido nuevo del paisaje y de la relación entre el entorno natural y la sociedad.

\subsubsection{El paisaje dividido}

A través de la gradación que acabamos de referir, y que nos conduce de forma paulatina de la expresión simbólica de la domesticación a su concreción económica, creemos que es posible entender algunos problemas prehistóricos importantes. En concreto, a la luz de estas consideraciones se podría hacer significativa esa otra gradación que se percibe en la Prehistoria del mundo atlántico europeo y que conduce del paisaje ceremonial sin referencias a lo cotidiano, a paisajes cada vez más mundanos.

En sentido diacrónico, esta gradación se concreta en la siguiente secuencia: en un primer momento (en horizontes neolíticos) se establecen tumbas y construcciones ceremoniales de carácter monumental que, paradójicamente, son replicadas por la invisibilidad casi absoluta de cuanto se refiere a la vida diaria de sus constructores (asentamientos, modo de vida, efecto nítido sobre el medio...); en un segundo momento (en la Edad del Bronce de las Islas Británicas y del noroeste europeo) los grandes monumentos ceremoniales son sustituidos por la imposición de grandes sistemas de parcelación del suelo y de campos cercados ${ }^{52}$ que van acompañados de la traducción ambiental cada vez más clara de las actividades humanas; y, en las postrimerías de la Prehistoria (a lo largo de la Edad del Hierro), la emergencia de centros urbanos o proto-urbanos y de asentamientos fortificados, unos y otros dotados

51. Del mismo modo que dentro de toda cultura hay una estrecha compatibilidad entre pensamiento, sociedad, subsistencia y racionalidad espacial, también existe una compatibilidad no menos fuerte ni importante entre todos esos niveles y el concepto de individuo que se usa dentro de esa comunidad. En Arqueología, uno de los campos prioritarios que tenemos para estudiar la definición del individuo arqueológico, es el mundo de la muerte. Así, mientras la muerte primitiva se concretaba en rituales de ocultación que en el instante supremo de la muerte afirmaban el predominio del grupo social al desinvidualizar totalmente al difunto, con la vida campesina, y sobre todo con el megalitismo, surge un reconocimiento del difunto, de la muerte y, poco a poco, del individuo, que hablan también de una nueva posición de la sociedad en relación con el tiempo y el espacio.

52. Aunque originalmente estos elementos no parecen constituir auténticos monumentos, desde nuestro punto de vista deben ser considerados como tales habida cuenta tanto de la intencionalidad a la que responden (i.e. expresar espacialmente una reclamación efectiva del territorio), así como de las características físicas de las que se revisten (i.e. perpetuación intencional o accidental a través del tiempo); véase en este sentido nuestro trabajo Criado 1993b. 
de un nítido carácter monumental y permanente, constituyen la característica esencial de los nuevos paisajes sociales ${ }^{53}$.

Esta variación representa formas distintas de paisajes domesticados. Cada una de ellas posee una configuración específica y reproduce la instauración de relaciones sociales y racionalidades productivas distintivas. Se podrían definir sucesivamente como paisaje delimitado, paisaje parcelado y paisaje jerarquizado.

Sin embargo, esta misma gradación se presenta en sentido sincrónico. En este caso ya no es una secuencia, sino una serie o grupo de transformaciones. Es bien sabido que en el neolítico de Europa occidental existe, en líneas generales, una simetría inversa que opone zonas con presencia de monumentos megalíticos funerarios en las que, en cambio, no se han descubierto apenas huellas de los habitats correspondientes, frente a otras zonas en las que la inexistencia de megalitos es replicada por una gran visibilidad y aparatosidad de los complejos domésticos. Esta situación divergente tal vez se pueda interpretar, en alguna de sus dimensiones, sobre la base de una práctica social que exige la visibilidad sobre el entorno del grupo humano, ya sea en clave funeraria o en clave cotidiana.

La elección de una de esas dos alternativas estaría sin duda en función de situaciones estratégicas y de prácticas sociales determinadas. Pues, en este sentido, la característica aparente de la situación campesina es constituir un fenómeno simbólico, social y tecno-económico relativamente homogéneo desde un punto de vista general, que sin embargo subsiste bajo la imposición de superestructuras socio-políticas y de dominación muy distintas.

No negaremos que a pesar de esta aparente homogeneidad, existen situaciones posibles muy distintas y que, a lo largo de la secuencia arqueológica atlántica, éstas se manifiestan con especial claridad. Sin embargo, también a pesar de las diferencias aparentes creemos que debajo de ellas existe una misma identidad estructural. Esta vendría dada por la presencia de tres características básicas: la relación entre sociedad y naturaleza se articula esencialmente bajo el principio de dominación de la segunda por la primera, la racionalidad económica se dirige hacia el desarrollo de procesos de acumulación (de trabajo, excedentes o capital), y la sociedad está cruzada por la división. Así, más allá de las características contextuales de cada situación específica, en todas ellas se refleja la conformación del espacio como territorio y la plena campesinización del paisaje. En términos espaciales, el resultado de este proceso será la emergencia de un paisaje, ya no cerrado, sino dividido. Sobre él, las estructuras de desigualdad y violencia generan no sólo efectos accidentales, sino sobre todo productos intencionales que representan de forma inequívoca las diferencias sociales.

Tal y como vimos en los subapartados precedentes, hasta estos momentos la acción social sólo se reflejaba en el espacio a través de sus efectos (deforestación) o de productos de carácter simbólicoritual (megalitos). A partir de este umbral, la intensificación en la destrucción y modificación del entorno y un amplio elenco de elementos de Cultura Material de todo estilo, expresarán la acción social sobre el espacio: límites, parcelas, caminos, murallas...

Estos elementos, además, en afortunada expresión del urbanista P. Virilio, establecen un espacio vertical que se contrapone al espacio horizontal no dividido (Virilio 1974). Mientras en éste las diferencias se yuxtaponen, en el otro se sobreponen unas a otras, configurándose de este modo ya no como distinciones sino como desigualdades.

53. Esta circunstancia también se percibe en la Prehistoria gallega y ha quedado plasmada en el célebre aserto de $F$. López-Cuevillas de que "los hombres megalíticos morían pero no vivían; los hombres castreños vivían pero no morían"; en el próximo apartado volveremos sobre ella. 


\section{DESARROLLOS: LOS PAISAJES DE LA ARQUEOLOGÍA}

Para finalizar este trabajo y ofrecer el contrapunto o necesario complemento "práctico" de una discusión que ha sido hasta aquí esencialmente teórica, deberíamos hacer dos cosas. Por una parte concretar una metodología que permita definir a través del registro arqueológico las diferentes estrategias de apropiación del espacio que hemos tratado. Y por otra aplicar los modelos que hemos propuesto a contextos empíricos específicos. Sin embargo, después de hacer unas consideraciones apresuradas sobre el primer tema, nos limitaremos en aras de la brevedad al segundo aspecto, tomando para ello como base el registro arqueológico gallego.

Nuestro objetivo, que en este punto sólo se puede plantear de forma hipotética y preliminar, es reconstruir la racionalidad y morfología de los paisajes que se suceden en la Prehistoria del noroeste peninsular ${ }^{54}$. Estas reconstrucciones, a pesar de su carácter hipotético, son consistentes con la evidencia empírica disponible y con los hechos que, no siendo conocidos para Galicia, se pueden extrapolar a nuestro país a partir de zonas y contextos arqueológicos próximos ${ }^{55}$.

Para realizar estas reconstrucciones, partimos de un planteamiento (especificado en Criado 1993a y 1993b) que se basa en el reconocimiento de la visibilidad como característica intrínseca a los elementos del registro arqueológico, y que intenta definir la actitud cultural hacia el espacio a través de la forma como se visibilizan los efectos y productos de la acción social. Para ello, partimos de la base de que las condiciones de visibilidad (espacial y/o temporal) de los elementos del registro arqueológico está determinada por una voluntad de visibilización que, por su parte, es compatible con las estrategias sociales de construcción del paisaje definidas anteriormente. El presupuesto en el que radica esta hipótesis es que la visibilidad es, de hecho, el resultado u objetificación de la concepción espacial subyacente al registro arqueológico.

De este modo, y simplificando en extremo, se puede preveer que dentro de una racionalidad primitiva la acción social no genera ni efectos (entendidos en sentido general como impacto sobre el ambiente) ni productos (entendidos como elementos de Cultura Material ya sean intencionales o no) cuya visibilidad se proyecte temporal y espacialmente y, además, tiende conscientemente a evitar u ocultar estos efectos. En los momentos de transición representados por la actitud participativa, estos efectos adoptan una proyección espacial intencionalmente visible. En ambos casos las únicas excepciones serían los monumentos salvajes que responden a una lógica específica. En cambio, dentro de una racionalidad doméstica, los productos y efectos sociales se reflejan en ambas dimensiones. Ahora bien, mientras que en las fases preliminares de constitución del modo de vida doméstico (representadas fundamentalmente por los paisajes monumentales) los productos visibles espacial y temporalmente poseen un carácter exclusivamente monumental, cuando la realidad se campesiniza totalmente, los productos visibles son tanto de carácter simbólico como funcional.

54. En la siguiente exposición soy deudor de mis colaboraciones en paleoecología con M.J. Aira y F. Díaz-Fierros a lo largo de los años (ver Criado et al. 1986), así como del trabajo realizado con varios compañeros (A. Bonilla, D. Cerqueiro, M. Díaz, M. González, F. Infante, F. Méndez, R. Penedo, E. Rodríguez y J. Vaquero) desde 1987 hasta la fecha en el marco del Proyecto de Arqueología del Paisaje financiado por la Dirección Xeral do Patrimonio Histórico e Documental de la Xunta de Galicia en la zona Bocelos-Furelos (Coruña), que nos ha permitido obtener un amplio registro empírico y plantear los modelos e hipótesis de trabajo que orientan esta línea de investigación (ver Criado et al. 1991).

55. Una exposición general de todos los datos empíricos que apoyan la traducción al registro arqueológico del NW peninsular de estos modelos se puede encontrar en Fábregas et al. 1992 y, más concreta, en Criado, González y Méndez 1994. 


\subsection{Paisajes Salvajes}

Tal y como dijimos en el apartado 2.2.2., un espacio no afectado por el hombre, que no refleja la acción social sobre él, que se configura en términos sociales en función de puntos o claves naturales prominentes, y que se desenvuelve en forma de líneas de movimiento y tránsito a su través que contribuyen, por lo tanto, a configurar la malla de aprehensión del terreno, devuelve las características fundamentales presentes en el Paleolítico y Epipaleolítico. En este espacio, que permanece abierto en sentido natural, la acción humana se resuelve en torno a núcleos de actividad y líneas de movimiento cerradas.

En Galicia los yacimientos de esta época son fundamentalmente de dos tipos: abrigos bajo o al lado de prominentes rocas y yacimientos al aire libre documentados por la aparición de material lítico en superficie. Estos yacimientos se sitúan alrededor de pequeñas cubetas o depresiones topográficas, en cuya base se encuentra una zona húmeda o braña. El patrón de distribución de los yacimientos alrededor de este tipo de zonas cerradas parece indicar que su disposición se efectuó con la intención de buscar y acotar áreas ricas en caza (pues son zonas de pasto y abrevadero) y adecuadas para la práctica de esta actividad y el control y acoso de animales (pues son zonas cerradas de fácil control visual), tal y como ha mostrado la investigación reciente (Cerqueiro Landín 1989).

Si además cogemos la malla de este tipo de yacimientos presentes en una zona reducida ${ }^{56}$, se observa que éstos se encuentran en gran multitud de casos en puntos desde los que se domina visualmente el terreno circundante. En este sentido existe una cierta diversidad de ámbitos de visibilidad que nos permite diferenciar entre yacimientos implicados exclusivamente con el dominio visual de los terrenos inmediatos (con radios de acción menores a $100 \mathrm{~m}$ ), yacimientos cuyo ámbito visible cubre el espacio completo de una braña o conjunto de brañas y, finalmente, yacimientos que ejercen un control visual a larga distancia.

En cualquiera de estos tres casos, y dentro de su ámbito correspondiente, los yacimientos líticos destacan con notoriedad sobre éste. Este rasgo es particularmente obvio en el caso de yacimientos vinculados a afloraciones rocosas. Tenemos por lo tanto una malla de puntos señeros, correlacionados con signos naturales visibles, que prestan la base para la aprehensión espacial de un paisaje dado.

Al mismo tiempo, entre estos puntos se establecen interrelaciones en clave de líneas de desplazamiento que los unen y de vinculación de los mismos a esta malla lineal (de configuración en espiral, como decíamos más arriba) que hace permeable el paisaje. Curiosamente, las relaciones que establecen estos puntos con sus vecinos más próximos coinciden con las líneas de tránsito a través del espacio que ocupan. De este modo se subraya el carácter de mojón de esos puntos naturales y se configura la base para la semantización social de ese entorno; (ver fig. 2.1 y 3 ).

La relación entre puntos y líneas de movimiento se puede documentar no sólo por el análisis topográfico, sino también observando el patrón de desplazamiento de animales como vacas y caballos que viven en régimen de libertad en el monte. Trabajos realizados en este sentido han mostrado, ante todo, que esos animales siguen una pauta de movimiento que reproduce las líneas de tránsito más económicas a través del territorio, y que son reutilizadas muchas veces por el hombre y por la red de caminos tradicionales. Estos estudios nos han permitido percibir una gran coinçidencia entre esas

56. Estos datos han sido recogidos en el curso del proyecto Bocelo-Furelos anteriormente citado, y han sido trabajados fundamentalmente por D. Cerqueiro Landín, (véase el capítulo de esta autora en el volumen Criado et al. 1991 y también Cerqueiro 1989). 
líneas de tránsito y la situación de yacimientos como los que ahora consideramos ${ }^{57}$. Igualmente se ha documentado que esas líneas no constituyen zonas de paso abiertas o ilimitadas, sino que están perfectamente definidas, cerradas sobre sí mismas y ceñidas muchas veces a la amplitud de una estrecha senda.

\subsection{Paisajes Monumentales}

La misma ambigüedad que citábamos en el apartado 2.2.3. respecto al momento y carácter que adoptó la emergencia de la plena humanización del entorno, también se presenta en Galicia, pues no en vano se ha discutido en qué medida y hasta que punto las comunidades megalíticas y del Bronce, que dejaron trás de sí una huella tan ténue que apenas se observan sus contornos, iniciaron la "artificialización" progresiva del medio natural, aunque todavía a pequeña escala, o si ésta únicamente se alcanzó con las sociedades castreñas, como ha sugerido en diferentes puntos A. de la Peña (1989 y 1992; 52 y ss.). De hecho en Galicia, al igual que en otras zonas de la Europa atlántica, el aparato técnico y el patrón de utilización del espacio que emerge claramente a partir de época tardorromana, parece (tal y como apuntábamos en trabajos anteriores: Criado 1988 y 1989c), estar ya presente en sus líneas generales dentro del mundo castreño prerromano.

En Galicia, al igual que en el resto del mundo atlántico, la primera domesticación del espacio (en el sentido que aquí hemos conferido a este término), se expresa con la construcción de un paisaje monumental a través del fenómeno megalítico.

Tal y como citamos anteriormente, este espacio monumental posee rasgos comunes y rasgos nuevos respecto al paisaje salvaje que le precede y al que, y esto es muy importante para valorar precisamente los rasgos comunes, en la mayor parte de los casos, sucede de forma directa.

Los rasgos comunes son, concretamente, la reutilización de líneas de tránsito a través del entorno y de elementos (o puntos) naturales significativos. Estos, en ocasiones, son abrigos rocosos con industrias líticas de momentos finales del Paleolítico y Epipaleolíticos.

Por su parte, las características nuevas son bastante obvias. En primer lugar encontramos la realización de construcciones artificiales y, de este modo, la creación artificial y permanente de juegos de espacios. Ahora bien, la petrificación de un espacio arquitectónico es, ante todo, un recurso para determinar la experiencia del observador: la relación de éste con la obra (su aproximación o alejamiento, el acceso a la construcción, la posición relativa frente a ella, su relación con el entorno), no depende tanto del observador individual, cuanto de un código que le es ajeno y le viene impuesto por la estructuración artificial del espacio. De este modo se establece, y esto también es nuevo, una regulación cultural de los hechos sociales. Esta regulación se encuentra en función de estrategias ideológicas e intencionales específicas.

Complementariamente, esta ordenación del espacio introduce asímismo, como rasgo novedoso y tremendamente significativo, la referencia al tiempo. Este había sido ajeno hasta el momento a la economía de subsistencia y a la estrategia de apropiación de la naturaleza propias de los grupos "salvajes" (ver Criado y Penedo 1989). El espacio no conoce el tiempo. Pero a partir de ahora, la aparición de monumentos que, con su permanencia y constancia, son auténticas "máquinas del tiempo", dispositivos que hacen presente el tiempo y su decurso, subraya una nueva economía de construc-

57. En este sentido se han realizado algunos ensayos, véase F. Infante et al. 1993. Desde una perspectiva mas general J. Vaquero ha insistido en la importancia de las líneas o clave de tránsito a través de un espacio dado como rasgo básico para entender la malla de yacimientos prehistóricos en esa zona, aunque su trabajo se ha aplicado al estudio de la localización de monumentos tumulares (Vaquero 1990). 
ción del paisaje que se basa, tanto como en la domesticación del espacio, en la petrificación del tiempo ${ }^{58}$. El hecho de que la monumentalidad megalítica y neolítica sea de carácter ceremonial y esté vinculada con la representación de ritos, contribuye a realzar esta circunstancia, pues no en vano el proceso ritual adopta la forma ante todo de un proceso temporal ordenado y, de este modo, se convierte en un instrumento de ordenación de la experiencia del tiempo que viven sus participantes.

Ahora bien, estas dimensiones del paisaje monumental no aparecen porque sí ni son meras observaciones que, subjetivamente, se nos pueden ocurrir frente a una construcción prehistórica. Antes bien son configuradas utilizando recursos materiales específicos entre los cuales destacan dos fundamentales que, en realidad, constituyen diferentes proyecciones del mismo: la arquitectura y el emplazamiento del monumento. Quiere ello decir que el ambiente espacio-temporal que expresan los monumentos tumulares gallegos y la relación de ellos con el observador se construye a través de la realización de un determinado plan arquitectónico y de la elección de un cierto punto de localización del monumento.

Dada la plasmación de ambos procesos en términos materiales, podemos precisamente descubrir a través de un análisis arquitectónico y del estudio de las condiciones de emplazamiento de las construcciones tumulares, la racionalidad de esos procesos y su relación con estrategias concretas de construcción del paisaje social. Este análisis se resuelve utilizando como instrumento metodológico el examen de la visibilidad. En líneas generales se trata de definir las condiciones de visibilización del monumento, de establecer a través de qué recursos se construyen sus condiciones de visibilidad (p.ej.: situación en ciertos puntos como líneas de horizonte, énfasis en sus elementos arquitectónicos o vinculación con otros elementos que destacan su presencia), y de descubrir las relaciones que a través de la visibilidad vinculan al monumento con otros elementos (habitats, asentamiento de las comunidades, elementos naturales ...).

Para ilustrar estos puntos, realizaremos a continuación un somero repaso de las características de localización de los túmulos o mámoas gallegas; (véanse como síntesis de esta argumentación las fig. 4 y 5).

De acuerdo con los trabajos realizados hasta la fecha ${ }^{59}$, la elección del emplazamiento de los monumentos estuvo determinado por la interacción de cuatro factores principales, que podían equilibrarse entre sí o, en otros casos, predominar unos sobre otros.

El primero de estos factores implicaba la vinculación de los monumentos con puntos de tránsito o vías de desplazamiento a través del terreno. Este factor de vinculación de la construcción es ilustrado perfectamente por el hecho de que exista una relación positiva entre la localización de las mámoas y (1) el patrón de movimientos de animales que viven en régimen de libertad, (2) caminos tradicionales, y (3) accidentes topográficos que posibilitan la comunicación entre zonas adyacentes en un espacio tan parcelado como el gallego.

Un segundo factor habría sido la vinculación con rocas y elementos naturales visibles y significativos. Nos referimos tanto a afloraciones rocosas de grandes proporciones y calidad visual, a cuyo margen es frecuente encontrar dispuestos los túmulos, como al posible prestigio de materiales como el cuarzo blanco (que se presentan repetidamente en las corazas que revisten los monumentos, como calzos no funcionales en las cámaras megalíticas, como posibles depósitos votivos en el túmulo o, también, como elementos de ajuar), o incluso a la elección de ciertas áreas o accidentes naturales que

58. A fin de cuentas es del dominio público que algunos megalitos monumentos arqueológicos estuvieron relacionados con la observación astronómica y sirvieron de calendarios; aunque a menudo se han exagerado estas dimensiones de los megalitos, su presencia es tan significativa respecto a la relación entre los monumentos y el tiempo, como su visibilidad lo es de la relación entre ellos y el espacio.

59. En esta exposición soy deudor de los trabajos realizados conjuntamente con mi compañe J. Vaquero Lastres. 
podrían haber poseido un carácter especial para construir las mámoas y, a veces, grandes necrópolis ${ }^{60}$ (nos referimos a a la cima de montañas y superficies que resultan visibles desde distancias que pueden oscilar entre 10 y $30 \mathrm{~km}$ a la redonda).

Tal y como se puede observar, en los dos puntos anteriores el emplazamiento de las construcciones tumulares se sirve de una reutilización de elementos propios del paisaje salvaje. La coincidencia entre las obras artificiales y un "mapa" de puntos y líneas "salvaje", podría haber sido, en primera instancia, un recurso "natural" que permitía enfatizar la construcción humana del paisaje. Además, también es posible que sirviera para establecer un nexo de continuidad entre los valores sociales que representaba el monumento y los valores simbólicos aparejados desde antes a esos elementos naturales. De esa forma, esa vinculación habría servido para crear un sentido de tradición y poner en relación la "nueva" tradición humana con la más vieja y mejor fundamentada tradición que está inscrita en la naturaleza.

Coincidiendo en parte con este sentido, el tercer factor de emplazamiento que podemos documentar es la vinculación de un monumento posterior a monumentos anteriores. Este factor habría dado lugar a la agregación de varios túmulos hasta formar pequeños o grandes grupos. También se documenta en los casos concretos en los que un monumento fue alterado a lo largo del tiempo en diferentes ocasiones o, sencillamente, construido sobre otro previo ${ }^{61}$. En todos esos casos, parece que la yuxtaposición de monumentos de momentos distintos fue un recurso para crear una imagen artificial de tradición social y afirmar así el funcionamiento como "máquina del tiempo" del monumento.

El último factor de emplazamiento que hemos reconocido es la vinculación de los monumentos con el espacio social y los habitats de las comunidades que los levantaron. Circunstancias como que los túmulos se hayan levantado sobre restos de ocupaciones anteriores (extremo documentado en varios casos en las excavaciones del complejo tumular de A Aboboreira -Baiao, norte de Portugal- realizadas por V. O. Jorge y colaboradores), o como el descubrimiento de yacimientos posiblemente coetáneos en sus proximidades ${ }^{62}$, plasmarían la relación entre espacio ritual y espacio doméstico de estos grupos. Esto no significa que nos decantemos por la existencia de un poblamiento estable en estos momentos vinculado de forma estrecha a las construcciones tumulares. Quiere decir exclusivamente que las zonas deprimidas, abrigadas, situadas alrededor de brañas y dentro del ámbito de visibilidad de los monumentos, parecen haber funcionado como polo de atracción, al menos en momentos episódicos, de las comunidades constructoras.

Un fenómeno en parte relacionado con el anterior, pero relativamente independiente, viene dado por la relación de los monumentos con espacios percibidos circularmente. La percepción más frecuente que se abre desde ellos o desde su alrededor, configura un espacio circular en el que el túmulo funciona como ombligo, telón o elemento delimitador: organiza la perspectiva a su alrededor y, normalmente, la cierra. Esta cualidad visual que, por otra parte, es compartida por monumentos tumulares de otras zonas europeas, es posible que en algunos casos sirviera para establecer una relación directa con el espacio del habitat. Pero en la mayor parte es posible que ese fenómeno tuviera que ver con el carácter escénico del monumento y con el código de aproximación cultural a éste. En cualquier caso se subraya con ello el carácter delimitado del paisaje monumental (ver fig. 4 y 5 ).

60. Los túmulos gallegos aparecen mayoritariamente distribuidos de forma aislada o formando pequeños grupos; sin embargo también es frecuente la aparición de grandes grupos que pueden llegar a reunir una veintena y hasta una cuarentena de túmulos; (sobre este tema y su relación con zonas de tránsito ver Criado y Fábregas A).

61. Ambos casos han sido documentados en las excavaciones de Forno dos Mouros (véase Criado et al. 1991) y del dolmen de Dombate (dirigida por J.M. Bello Diéguez).

62. Estos datos están en curso de estudio por parte de M. González Méndez; una primera aproximación a los mismos se puede ver en los capítulos de esta autora y de Criado y Vaquero en el volumen Criado Boado et al. 1991, o también en González Méndez 1989a y 1989b. 
Si esto último es cierto, entonces veríamos que la estrategia de apropiación de la naturaleza que subyace debajo de este espacio monumental da lugar (fig. 2.2 y 4), en primera instancia, a un mapa de puntos y líneas que, a diferencia del paisaje salvaje, se configura con base en obras artificiales en vez de reutilizar meramente elementos naturales, y sobre el que se imponen, además, la presencia y significación de ciertas áreas de actividad abiertas.

Estas áreas que, debido al carácter no permanente del asentamiento y del cultivo de rozas en sectores de monte existentes en estos momentos ${ }^{63}$, conforman zonas de ocupación no estables, cambiantes y abiertas, constituyen un espacio humanizado de círculos aislados en medio de un ambiente silvestre, cuyo aprovechamiento seguirá siendo todavía importante. Por su parte, las relaciones visuales y la presencia de construcciones monumentales, al tiempo que contribuye a resaltar la apertura de esas zonas de actividad y ocupación, establecen una nítida delimitación del espacio natural.

Estas características son tanto más notables, cuanto que son coherentes con el hecho de que en estos momentos el habitat y las estructuras de poblamiento, cuando se consideran desde la perspectiva del tiempo, sean invisibles. Pues, en efecto, la levedad de las aldeas y asentamientos de estas épocas es tal, que su localización ha desafiado hasta fecha reciente la investigación arqueológica.

Si tenemos en cuenta, además, que esta circunstancia es muy genérica en el Neolítico y Megalitismo de la fachada atlántica, deberíamos entender que la conjunción de la monumentalización de la muerte con la invisibilización del asentamiento, nos habla de una estrategia social en la que comienza la domesticación efectiva del entorno, pero todavía no trivializa ésta hacia el terreno de lo más práctico y mundano, y que es coherente con el carácter aislado y silvestre de este tipo de paisaje. Mientras la domesticación perpétua de la naturaleza se escribe a través del orden de lo simbólico, funerario y ritual, el orden de lo cotidiano todavía habría representado una domesticación efímera de lo natural. Situación que, en su ambiguedad, es por demás coherente con el momento de tránsito que parece implícito en el Neolítico y el megalitismo, y que hemos comentado en el apartado 2.2.3.

\subsection{Paisajes Parcelados}

A partir del punto anterior, se sitúan una serie de situaciones que, si bien se empiezan a entrever, no se pueden perfilar por carecer de la información suficiente.

En este caso se encuentran, fundamentalmente, el paisaje o paisajes que habrían ocupado el espacio de tiempo que media entre la última etapa constructiva importante de monumentos funerarios y los primeros asentamientos fortificados. En este lapso, que se corresponde con la Edad del Bronce, se presentan al menos dos tipos de evidencias distintas, cada una de las cuales representa, tal vez, una forma diferente de actualizar los mismos principios organizativos y la misma racionalidad espacial.

De un lado tenemos la evidencia de asentamientos al aire libre, amplios, posiblemente reocupados episódicamente, que dan así lugar a la creación de, en afortunada expresión de F. Méndez, áreas de acumulación de material, y que poseen un patrón de distribución y emplazamiento muy característico. En general se sitúan siempre en zonas de monte, en el piso topográfico inmediatamente superior al ocupado por las aldeas y terrenos de cultivo intensivo actuales. Puntualmente se vinculan a brañas de

63. Esta posibilidad, que ha sido planteada hipotéticamente en virtud de diferentes indicadores (distribución de los monumentos tumulares, presencia de molinos, datos polínicos indirectos, inferencias socio-éconómicas...), se verifica en parte con la presencia de polen de cereal en el paleosueolo contenido bajo un túmulo de la Sierra de O Bocelo, (análisis realizado por P. López, del Departamento de Prehistoria del CSIC). 
cierto desarrollo y que podrían haber sido utilizadas como zonas de reserva de humedad para pasto de verano ${ }^{64}$.

Si los datos recogidos en la Sierra de O Bocelo sobre la existencia de fosos lineales en tierras de monte en los alrededores del yacimiento de A Lagoa, demuestran finalmente ser coetáneos de este yacimiento, entonces tendríamos documentado un posible sistema de parcelación del campo o de diques que aislaban el conjunto del yacimiento o áreas funcionales del mismo. Esta posibilidad es precisamente tanto más importante por cuanto, en un momento intermedio entre el megalitismo y el mundo castreño, establecería la transición paulatina hacia la visibilidad y monumentalización del habitat característica de esta última etapa.

En este caso, podríamos empezar a hablar de un paisaje parcelado que, de forma semejante al que se documenta en otras zonas europeas, también habría existido en Galicia. De este modo se vislumbrarían los contornos de un tipo de paisaje que se cierra, que define la apropiación privada del suelo (sea a nivel de una única comunidad, grupo social o individuo) y que, en definitiva, marcaría una forma de construcción del paisaje representada por la definición de territorios y delimitación de propiedades. Este desarrollo es tanto más significativo, cuanto que sucede y, a un nivel general, sustituye, al paisaje monumental megalítico, ejemplificando así el mismo tipo de secuencia que se documenta en otras zonas atlánticas europeas. En este sentido, también sería muy significativa su relación con signos claros de diferenciación social en este momento (representadas en armas y, sobre todo, en las obras de joyería que implicaban la atesorización y expropiación de trabajo y bienes en beneficio de un individuo o grupo de individuos). Tal y como interpreta F. Méndez, estos desarrollos se deberían entender en relación con la presencia de una racionalidad económica enfocada hacia la acumulación del producto del trabajo excedente; este proceso se habría dado a través de la posesión de ganado vacuno, lo que implicaría la necesidad de apropiarse de las zonas de pasto extremo que, por demás, se documenta en la estrecha relación de yacimientos y brañas (Méndez 1992).

Una situación totalmente distinta parece, en principio, estar representada por los petroglifos de la Edad del Bronce. Ahora bien, dada la especificidad y localización de la distribución del arte rupestre en Galicia, que lejos de encontrarse disperso uniformemente por toda la geografía gallega se ciñe a ambientes de costa y prelitorales respaldados por zonas montañosas y de relieve abrupto, es posible que la existencia de este fenómeno sea significativa precisamente a la luz de la oposición con la situación que podría estar vigente durante el Bronce en el resto del país.

Los petroglifos, por su propia objetificación, son hitos espaciales que construyen un tipo específico de paisaje. Sin embargo, la primera característica peculiar de este paisaje habría sido el estar expresado en términos de representaciones artísticas. No es un paisaje que se vertebre alrededor de principios organizativos reales, sino que éstos son figurados.

Por otra parte, aunque los petroglifos son obras permanentes, su escasa proyección visual en términos espaciales no nos permite definirlos como monumentos en sentido estricto. A pesar de ello, fueron hechos en multitud de ocasiones para dominar amplias zonas de terreno o, en casos de panorámicas más restringidas, áreas significativas. Por otra parte, su localización sobre rocas que poseen algún rasgo notorio (ser la mayor de su contorno u ocupar un punto de emplazamiento específico), permite suponer que, al menos en gran número de ocasiones, los petroglifos fueron hechos otorgando una especial significación al punto sobre el que se hacían y con la intención clara de hacerlos visibles. Por estas razones, los petroglifos podrían ser definidos como monumentos ambigüos.

64. Después de cinco años de trabajo en la Sierra de O Bocelo, este conjunto de yacimientos se empieza a conocer bastante bien $y$, en poco tiempo, se podrán definir los rasgos generales del paisaje y racionalidad social que habrían configurado, (ver los trabajos de Méndez Fernández 1989, 1992 y en el volumen Criado et al. 1991). 
R. Bradley (1991a y 1992) ha estudiado desde la perspectiva de la Arqueología del Paisaje la distribución de petroglifos en diversas zonas inglesas. De acuerdo con sus propuestas, los petroglifos organizaban el paisaje a través de una geografía de lugares y movimientos, de zonas puntuales y de líneas de desplazamiento entre ellas. Desde su punto de vista, este tipo de construcción del paisaje estaba muy próxima a la de los pueblos cazadores-recolectores (ver apartados 2.2.2. y 2.2.3.). Interpreta esta coincidencia como indicativa de que los grupos que representaron los petroglifos poseían un modo de vida móvil, posiblemente acomodado a la explotación de recursos itinerantes y silvestres (caza o pastoreo).

Algunas de estas sugerencias se podrían aplicar a Galicia. A falta de un estudio más detenido ${ }^{65}$, parece bastante claro que una buena parte de los petroglifos gallegos se vinculan a áreas deprimidas o pequeñas cubetas en zonas más o menos altas y húmedas (con presencia de brañas). Este tipo de zonas son aptas para reunir animales y mantenerlos controlados. La presencia de escenas de caza, conducción de animales y equitación en los petroglifos que se encuentran en su alrededor, podrían haber representado el tipo de acciones que se realizaban en esos ambientes. Además de ello, los petroglifos se sitúan en puntos y zonas de paso, y hasta es posible que marquen en ocasiones las líneas de tránsito a través del terreno. Es significativo el que, en petroglifos que representan animales en movimiento o huellas, la dirección de unos y otras parezca en principio coincidir con la línea general de tránsito viable en la zona en la que se encuentran.

Con todo, aún cuando la interpretación que vincula los petroglifos a comunidades móviles fuera aplicable a Galicia, la realización de petroglifos supone la "construcción" de una obra artificial que concreta un efecto intencional permanente y, además, generalizado del hombre sobre el medio. En este sentido, la relación entre la cultura y el medio natural que documentan se sitúa en las coordenadas que describimos al hablar del "paisaje domesticado" 66.

De hecho, la relación directa de los petroglifos con habitats cotemporáneos, es posible que sea más estrecha de lo que en principio podría parecer. En algunos casos (Tourón en Pontecaldelas ${ }^{67}$ o Fixón en Cangas, ambos en la prov. de Pontevedra) existe un habitat situado en el centro de la cuenca en torno a la cual se distribuyen los petroglifos. Esta circunstancia permite matizar la diferencia entre zonas con y sin petroglifos antes citada. De hecho, de acuerdo con los trabajos en curso de F. Méndez, en estas zonas gallegas habría existido durante esta época el mismo tipo de racionalidad socioeconómica que se citó más arriba. En este caso, deberíamos entender los paisajes con y sin petroglifos como dos formas distintas de articular y configurar el mismo tipo esencial de paisaje social. Es más, si tenemos en cuenta que en ambas situaciones es posible leer en el registro arqueológico la presencia de una sociedad de tipo heróico conformada por pequeños grupos domésticos, dominados por varones guerreros que expropiaban en su beneficio los excedentes en trabajo y productos de su grupo o de otros grupos, entonces sería factible interpretar que el paisaje configurado a través de los petroglifos es el resultado de una ideología heróica de exaltación de valores masculinos y belicosos, en la que el movimiento a través del territorio y la relación con zonas económicamente atractivas, en vez de ser

65. Y que está ahora mismo en marcha por parte de R. Bradley, R. Fábregas y el que suscribe; sus resultados se avanzan en Bradley et al. 1994

66. Este tipo de actitud espacial, que a un cierto nivel establece el dominio de la sociedad sobre la naturaleza, es coherente con detalles estilísticos y de diseño de los petroglifos que muestran un concepto del espacio ordenado en función de criterios exteriores a la naturaleza misma. En este sentido apuntan la búsqueda de un marco que contenga a las figuras representadas ( $y$ que no se crea artificialmente, sino utilizando los contornos y fisuras de la propia roca), o la existencia de una única línea de tierra homogénea para disponer las figuras sobre la roca.

67. Datos en curso de estudio por M. Santos Estevez. 
una función infraestructural o subsistencia, es una forma de apropiación del territorio mediatizada por guerreros. Como es rasgo notorio en diferentes tipos de sociedades heróicas, la ideología del guerrero necesita "asilvestrar" a éste y emanciparlo del ambiente doméstico.

A través de ambos hechos espaciales, por lo tanto, y a pesar de las insuficiencias del registro documental, creemos que se percibe con claridad el desarrollo paulatino de la campesinización (independientemente incluso del hecho de que se practique o no una agricultura propiamente campesina) hacia el mundo natural. De este modo se entendería mejor la secuencia de paisajes prehistóricos en Galicia y se matiza la supuesta eclosión que parece representar el mundo castreño posterior.

\subsection{Paisajes Jerarquizados}

A finales de la Prehistoria, en el momento ocupado por las sociedades castreñas (desde el siglo VIII a.C. hasta el II d.C.), encontramos en Galicia los indicadores de un tipo totalmente distinto de racionalidad espacial y de sistema de apropiación de la naturaleza.

La tendencia hacia un paisaje cada vez más artificializado, más interferido intencional y activamente por los grupos humanos, se ha intensificado. Pero esa es la única línea de semejanza entre lo que ocurre en la Prehistoria tardía y el "paisaje monumental" anterior. Aunque situados dentro de una misma línea de progresión y racionalidad, el paisaje campesino y jerárquico representa una realidad esencialmente distinta a la ofrecida por las situaciones comentadas en los subapartados precedentes (fig. 2.3 y 6 ).

La aparición de un ambiente ecológico plenamente humanizado, de un asentamiento permanente fortificado y de carácter monumental y de una posible compartimentación artificial del suelo, nos conducen a un paisaje social sobre el que se inscriben los efecos de la jerarquización social y del establecimiento de modos de vida y pensamientos claramente campesinos. El último rasgo citado, en concreto, es por el momento una hipótesis en estudio. Sin embargo, amparándonos en la estrecha relación entre castros y sistemas de parcelación del suelo como terrazas, bancales de cultivo o agras que se documenta en casos como el ofrecido en la figura 6, así como en la posible existencia de sistemas de parcelación del monte, es factible proponer que alguno de estos elementos puedan haber estado presentes en época castreña ${ }^{68}$.

Una característica importante de este paisaje social es, sobre todo si se compara con el paisaje ceremonial megalítico, la invisibilidad completa que existe respecto a las estrategias y estructuras funerarias. Salvo datos parcos en este sentido, no tenemos documentación sobre la muerte.

De este modo, el paisaje social de este momento se construye a través de unas obras monumentales que no son puntos de carácter ceremonial, sino áreas cerradas sobre sí mismas de carácter doméstico y funcional. En vez de existir entonces una malla de líneas que unen espacios abiertos y transparentes, tenemos una constelación de zonas cerradas, circunscritas, conectadas directamente con el grupo doméstico, y aisladas de las vecinas. En términos de Ingold, en este espacio el paisaje se ha convertido en territorio (Ingold 1986: 143 y ss.). Sobre él, además, el privilegio de la función guerrera impone la configuración de un paisaje fortificado que habla de la división y de un tipo de formación social que se puede definir bien bajo el concepto de sociedad heróica. Con él nos referimos hipotéticamente a grupos sociales dotados de un bajo nivel de integración supralocal, aislados en unidades independientes y en los que, sobre la base ofrecida por una subsistencia campesina que vive del trabajo de la tierra efectuado fundamentalmente por mujeres y niños, se establecen cofradías de guerreros dedicados al

68. Estos datos se pueden consultar, respectivamente en Criado et al. 1991: 248-9 y en Díaz Vázquez et al. 1992. 
pillaje y bandolerismo como forma de expresión de una compleja estructura ideológica de origen indoeuropeo ${ }^{69}$.

En este contexto social, el nuevo paisaje fortificado encontraría su racionalidad última en el hecho de que el espacio ha dejado de ser meramente el ambiente de la producción, para convertirse en la condición infraestructural básica de la producción (medio natural de la misma, como decía Marx).

Las diferencias que apartan al mundo ceremonial tumular (muertos monumentales y vivos invisibles), del mundo castreño (muertos invisibles y vivos monumentales), representa el cambio en las estrategias sociales de construcción y representación de la realidad (de uso y concepción del espacio), que ha ocasionado la adopción de un modo de vida plenamente campesino, de una sociedad dividida y de unas organizaciones jerarquizadas.

La ulterior parcelación del campo que da lugar a un paisaje dividido en épocas históricas posteriores (fig. 2.4), refleja, a través de una compartimentación extrema del espacio, el resultado final de este proceso, e inicio de nuevas y más modernas historias: la constitución de la tierra como producto primero y mercancía después ${ }^{70}$.

\section{CONTROVERSIAS}

Son muchas las cuestiones que quedan pendientes.

Desde una perspectiva empírica es necesario intensificar las investigaciones antes de que podamos concretar los modelos generales que hemos propuesto.

Y desde el plano teórico, por su parte, se podría alegar que las propuestas contenidas en este trabajo, con su insistencia en temas cognoscitivos y con su aparente indiferencia a explicar por qué ocurren las cosas que se dice que ocurrieron o, simplemente, cómo se pasó de cada una de las regularidades consideradas a otras, representan un buen ejemplo de ejercicio idealista en Arqueología. Sin entrar al trapo de esta etiqueta, sino situándonos al margen de la categorización que ella implica, creemos necesario subrayar una vez más que hace ya tiempo que entraron en crísis la noción de realidad identificada únicamente con lo material ${ }^{71}$, la creencia de que existe un universo mecánicamente determinista y, por supuesto, la ilusión de que la realidad puede ser representada unívocamente.

En cambio, situados en el umbral de la crísis definitiva de los valores modernos, el materialismo, el determinismo y el objetivismo tienen que reencontrar su camino tratando a todos los fenómenos de la realidad social como materialidades. Ello implica no sólo reconocer su plena existencia, sino además definir tanto las relaciones que se establecen entre ellos y con la sociedad como los efectos reales que producen.

69. Este último punto se apoya en las investigaciones realizadas sobre la guerra y religión de las sociedades castreñas del NW peninsular por B. García Fernández-Albalat (1990); aunque sus propuestas han sido contestadas por parte de arqueólogos gallegos (por ej. A. de la Peña 1992: 53 y 54) y no gallegos, tienen la virtualidad de hacer comprensibles aspectos del mundo castreño a los que desde parámetros arqueológicos se les otorgan explicaciones que rayan en lo risible como, por ejemplo, el mero hecho de la presencia de grandes fortificaciones en una sociedad que según el registro arqueológico parece pacífica y no belicosa.

70. Mientras no se definan las posibilidades planteadas en este trabajo sobre la génesis en la Edad del Bronce o del Hierro del paisaje parcelado, debemos seguir reconociendo que este proceso en Galicia no se habría dado hasta épocas romanas y medieval.

71. Esta idea, con la que hemos trabajado en otros trabajos (por ej. Criado 1989a y 1989b), se puede encontrar argumentada en Naredo 1987, particularmente pág. 476 y ss. 
Situada en el torbellino de ese contexto e intención, la propuesta que se expresa en este trabajo intenta establecer un nivel común sobre el cual se hagan intercomprensibles acontecimientos de la realidad descompuestos por la especificidad de los procedimientos analíticos e interpretativos de uso frecuente dentro de la Arqueología. Estos útiles han estado hasta ahora orientados fundamentalmente hacia la inmediatez física de los datos empíricos, de las relaciones funcionales y de las explicaciones materialistas dentro del registro arqueológico. De ahí deriva precisamente el efecto disgregador, desmigajante, de las prácticas de investigación social modernas.

Para superar esta fragmentación empobrecedora, es por lo que adoptamos en este texto una perspectiva de carácter general. Es cierto que nos pueden replicar que las cosas que se dicen poseen presunciones de globalidad o que sólo son ciertas si son concretas. En alivio de ambas críticas, subproducto de un pensamiento superficialmente post-moderno la primera y reminiscencia de una actitud empirista la segunda, podemos alegar que si el análisis generaliza es (como en la buena sociología) para, por un lado, afirmar más claramente la especificidad de los hechos considerados y, por otro, para facilitar la introducción dentro de la práctica arqueológica de unos ámbitos de análisis que, o bien han estado apartados de ella, o bien no se cree que puedan ser abordados por ella. Para hacer cognoscibles esas temáticas es necesario ante todo adoptar una imaginería mental que posibilite pensarlas. La intención básica de este texto es contribuir a la constitución de un nivel de aprehensibilidad intersubjetiva de los fenómenos considerados. Es cierto que toda recuperación de una escala de interaprehensibilidad en realidad constituye una metáfora ${ }^{72}$. En nuestro caso esa metáfora se describe textualmente en las páginas precedentes y se resume gráficamente en la figura 2.

Una vez que aclaramos que este texto es una metáfora y que sabemos qué es una metáfora, también sabemos que la labor fundamental que debería desarrollar la crítica disciplinar es valorar la pertinencia y legitimidad de las metáforas movilizadas dentro de nuestra práctica arqueológica. Quiere ello decir, sobre todo, decidir hasta qué punto el sentido implícito que presuponen esas metáforas, la orientación en la que inclinan nuestro pensamiento, es lícita o espúrea.

Precisamente por ello, dado que el tipo especial de valores intelectuales que crean la Historia y la Arqueología, no derivan su legitimidad de sus presuntas condiciones de autenticidad, sino que acceden a ella en gran medida o bien a través de la economía interna del discurso académico (como ocurría antes y sigue todavía ocurriendo ahora), o bien a través del refrendo social (como ocurre ahora y debería ocurrir cada vez más), una vez que se compruebe que las propuestas planteadas se acomodan bien a las características del registro empírico disponible, su aceptación o rechazo dependerá de la sanción académica o de la aprobación social. En el primer caso es probable que el paradigma tradicional moderno siga vigente todavía bastante tiempo. En el segundo es posible que las nuevas propuestas alternativas se establezcan y mantengan mientras duren las inquietudes sociales que concuerdan con ellas.

72. La metáfora puede ser entendida como un género de discurso cuya función es provocar un cambio en la forma como vemos las cosas, operar una transformación en nuestro pensamiento, a través de la fuerza que las palabras (y las imágenes, podemos añadir) tienen para nosotros (Madison 1990: 188). 


\section{REFERENCIAS BIBLIOGRÁFICAS}

BAHUCHET, S., Y GUILLAUME, H. 1982. Aka-farmer relations in the northwest Congo Basin. In E. Leacok y R. Lee (eds.); Politics and history in band societies. Cambridge: Cambridge University Press and Edit. de la Maison des Sciences de l'homme, pp. 189-212.

BARRETT, J.C. 1990. The monumentality of death: the character of Early Bronze Age mortuary mounds in southern Britain. World Archaeology 22 (2), pp. 179-89.

BATE, L.F. 1986. El modo de producción cazador-recolector o la economía del salvajismo. Boletín de Antropología Americana 16, pp. 5-32.

- 1989. Notas sobre el Materialismo Histórico en el proceso de investigación arqueológica. Boletín de Antropología Americana 19, pp. 5-29.

BENTHAM, J. 1989. El Panóptico. Madrid: Edic. La Piqueta, (2 $2^{\mathrm{a}}$ edic., $1^{\mathrm{a}}$ edic. Edic. Endymion, 1979; edic. orig. Madrid: 1822).

BERMEJO BARRERA, J.C. 1986. O final da Historia: ensaio de Historia teórica. Vigo: Ediciós Xerais.

- 1987. El final de la Historia. Ensayos de Historia Teórica. Madrid: Akal.

- 1991. Fundamentación lógica de la Historia. Introducción a la Historia Teórica. Madrid: Akal.

BLACKBURN, R.H. 1982. In the land of milk and honey: Okiek adaptations to their forests and neighbours. In E. Leacok y R. Lee (eds.), Politics and history in band societies. Cambridge: Cambridge University Press and Edit. de la Maison des Sciences de l'homme, pp. 283-305.

BOUHIER, A. 1979. La Galice. Essai geographique d'analyse et d'interpretation d'un vieux complexe agraire. Poitiers: A. Bouhier; 2 tomos.

BRADLEY, R. 1991a. Rock Art and the Perception of Landscape. Cambridge Archaeological Journal 1, pp. 77-101.

- 1991b. The pattern of change in British prehistory. In T. Earle (ed.) Chiefdoms: Power, Economy and Ideology, Cambridge: Cambridge University Press, pp. 44-70.

- 1992. Turning the world: rock carvings and the Archaeology of Death. In N. Sharples y A. Sheridan (eds.) Vessels for the ancestors, Edinburgh.

- 1993. Altering the Earth. The Origins of Monuments in Britain and Continental Europe. Edinburgh: Society of Antiquaries of Scotland.

BRADLEY, R., CRIADO BOADO, F. Y FÁBREGAS VALCARCE, R. 1994. The location of petrogliphs. A case study from Galicia. World Archaeology; en prensa.

BRAUDILLARD, J. 1981. El espejo de la producción. Barcelona: Gedisa, (Le miroir de la production, Paris: Casterman, 1973); 178 pp. 1983 Cultura y simulacro. Barcelona: Kairós, (Paris, Editions Galilée, 1978).

CERQUEIRO LANDÍN, D. 1989. La utilización del espacio en el Paleolítico: patrón de asentamiento en la Sierra de O Bocelo. Santiago: Fac. Xeografía e Historia, Trabajo de Investigación del Tercer Ciclo.

CHORLEY, R.J. 1975. La Geografía como Ecología Humana. In R. J. Chorley (ed.), Nuevas tendencias en Geografía. Madrid: Instituto de Estudios de Administración Local, (Directions in Geography, London: Methuen y CO., 1973), pp. 225-48.

CLASTRES, P. 1979. A sociedade contra o Estado. Porto: EdiÇoes Afrontamento, (Paris: Minuit, 1974).

- 1981. Investigaciones en Antropología Política. Barcelona: Gedisa, (Recherches d"anthropologie politique, Paris: Seuil, 1980). 
- 1986. Crónica de los indios Guayakis. Lo que saben los Aché, cazadoras nómadas del Paraguay. Barcelona: Alta Fulla, (Paris: Plon, 1972).

CLAVAL, P. 1981. Evolución de la Geografía Humana. Barcelona: Oikos-Tau, (edic. orig. 1974).

CRIADO BOADO, F. 1988. Arqueología del Paisaje y Espacio Megalítico en Galicia. Arqueología Espacial, 13. Teruel: Colegio Universitario de Teruel.

- 1980. Catalogación de mámoas en los municipios de Curtis, Sobrado y tierras adyacentes. Brigantium 1, pp. 13-40.

- 1989a. Megalitos, Espacio, Pensamiento. Trabajos de Prehistoria, 46: 75-98.

- 1989b. "We, the post-megalithic people ...". In I. Hodder (ed.) The Meaning of Things. Material

Culture and Symbolic Expression. London: Unwin Hyman, pp. 79-89.

- 1989c. Asentamiento megalítico y asentamiento castreño: una propuesta de síntesis. Gallaecia 11, pp. 109-37.

- 1993a. The visibility of social action and the interpretation of material culture. In I. Hodder y M. Shanks (edis.) Interpretatives archaeologies, Oxford: Blackwells; en prensa.

- 1993b. Visibilidad e interpretación del registro arqueológico. Trabajos de Prehistoria, 50; en prensa.

CRIADO BOADO, F. Y FÁBREGAS VALCARCE, R. A. Regional patterning among the Megaliths of Galicia (NW Spain). Proceedings of Prehistoric Society; en prensa.

CRIADO BOADO, F., BONILLA RODRÍGUEZ, A., CERQUEIRO LANDÍN, D., INFANTE ROURA, F., GONZÁLEZ MÉNDEZ, M., MÉNDEZ FERNÁNDEZ, F., PENEDO ROMERO, R., RODRÍGUEZ PUENTES, E., VAQUERO LASTRES, J. Y VÁZQUEZ DÍAZ, M. 1991. La Arqueología del Paisaje en Galicia. El área Bocelo-Furelos entre los tiempos paleolíticos y medievales. (Campañas de 1987, 1988 y 1989). Arqueoloxía-Investigación, 6. Santiago: Xunta de Galicia, Dirección Xeral do Patrimonio Histórico.

CRIADO BOADO, F., GONZÁLEZ MÉNDEZ, M. Y MÉNDEZ FERNÁNDEZ, F. 1994. Dynamics without change: Galican prehistory during the fourth, third and second millenia b.c. In S. Keay, I. Lisboa et al. (eds.) Dynamics of change in Iberian Peninsula.

CRIADO BOADO, F. Y PENEDO ROMERO, R. 1989. Arte de cazadores y arte de salvajes: una contraposición entre el arte paleolítico y el arte post-glaciar levantino. Munibe , 41: 3-22.

DETIENNE, M. 1980. Los jardines de Adonis. Madrid: Akal.

DÍAZ-FIERROS VIQUEIRA, F. AIRA RODRÍGUEZ, M.J., CRIADO BOADO, F. et al. 1992. Paleoecología y Prehistoria de un Paisaje Rural; en prensa.

DÍAZ VÁZQUEZ, M., CRIADO BOADO, F. Y MÉNDEZ FERNÁNDEZ, F. 1992. Dinámica de pendientes y acción antrópica en Galicia: un caso de estudio derivado de la Sierra de O Bocelo (Coruña). II Reunión Nacional de Geoarqueología, (Madrid, diciembre); en prensa.

DOLLFUS, O. 1976. El espacio geográfico. Barcelona: Oikos-Tau, (L'espace geographique, Paris: Presses Universitaires de France, 1976).

DUVIGNAUD, J. 1974a. Voz Sociología rural. In J. Duvignaus (dir.) La sociología. Guía alfabética. Barcelona: Anagrama, (París: Denoël, 1972).

- 1974b. Voz Tipo de Sociedad. In J. Duvignaus (dir.) La sociología. Guía alfabética. Barcelona: Anagrama, (París: Denoël, 1972).

- 1977. El lenguaje perdido. Ensayo sobre la diferencia antropológica. México: Siglo XXI, (Paris: PUF, 1973).

Eco, U. 1968. La estructura ausente. Introducción a la Semiótica. Barcelona: Lumen, (Milano: 1968).

FÁBREGAS VALCARCE, R. Y RUIZ-GÁLVEZ PRIEGO, M. 1992. Funerary and domestic domains 
in the Prehistory of the NW Iberian Peninsula. In M. Edmonds y C. Richards (org.) Social Life and Social Change in the Neolithic of North-Western Europe, (Glasgow, septiembre 1992); en prensa. FOUCAULT, M. 1978. Las palabras y las cosas. México: Siglo XXI, (novena edic.; 1968 primera edición; Paris, Gallimard, 1966).

- 1979. La arqueología del saber. México: Siglo XXI, (sexta edición; 1970 primera edición; L"archeologie du savoir, Paris: Gallimard, 1969).

- 1980a. Historia de la sexualidad. 1. La voluntad de saber. Madrid: Siglo XXI, (tercera edición; 1977 primera edición; Histoire de la sexualité. 1. La volonté de savoir, Paris: Gallimard, 1976).

- 1980b. Preguntas a Michel Foucault sobre la Geografía. In M. Foucault Microfísica del Poder. Madrid: Ediciones de La Piqueta, (Paris, 1978), pp. 111-24.

- 1980c. Poderes y estrategias. In M. Foucault Microfísica del Poder. Madrid: Ediciones de La Piqueta, (Paris, 1978), pp. 163-73.

- 1980d. Verdad y Poder. In M. Foucault Microfísica del Poder. Madrid: Ediciones de La Piqueta, (Paris, 1978), pp. 175-89.

- 1980e. Entrevista sobre la prisión: el libro y su método. In M. Foucault Microfísica del Poder. Madrid: Ediciones de La Piqueta, (Paris, 1978), pp. 87-102.

- 1984. Vigilar y castigar. Madrid: Siglo XXI, (cuarta edición; 1978 primera edic.; Surveiller et punir, Paris: Gallimard, 1975).

- 1989. El ojo del poder. In J. Bentham 1989: 9-28, (L'oeil du pouvoir, Paris: Edit. P. Belfond). Fumagalli, V. 1989. Las piedras vivas. Ciudad y naturaleza en la Edad Media. Madrid: Nerea, (Bologna, 1988).

GARCÍA FERNÁNDEZ-ALBALAT, B. 1990. Guerra y religión en la Gallaecia y la Lusitania antiguas. Coruña: Ed. do Castro.

GODELIER, M. 1976. Antropología y Biología. Barcelona; Anagrama, (Revue Internationale des Sciences Sociales, XXVI, 4, 1974).

GONZÁLEZ MÉDEZ, M. 1989a. Aproximación a los asentamientos del IV y III milenios en la Sierra de O Bocelo. Coloquio Galaico-Minhoto, (Lugo, septiembre); en prensa.

- 1989b. Asentamiento y Cultura Material en los Yacimientos del III milenio a.C. de la Sierra de O Bocelo y del valle del río Furelos. Santiago: Fac. Xeografía e Historia, trabajo de inv. del tercer ciclo.

Goody, J., (ed.) 1975. Literacy in traditional societies. Cambridge: Cambridge University Press, (1a edic. de bolsillo, edic. orig. Cambridge, 1968).

- 1985. La domesticación del pensamiento salvaje. Madrid: Akal editor, (Cambridge, 1977).

- 1987. A Lógica da escrita e a organizacao da sociedade. Lisboa: Edicoes 70, (Cambridge, 1986).

Grande del Brío, R. 1982. El lobo ibérico. Salamanca.

Hernando Gonzalo, A. 1993. El proceso de Neolitización: perspectivas teóricas para el estudio del Neolítico. Zephyrus, en prensa.

HODDER, I. 1984. Burials, houses, women and men in the European neolithic. In D. Miller y C. Tilley (eds.) Ideology, power and prehistory. Cambridge: Cambridge University Press, pp. 51-68.

- 1986. Reading the past. Current approaches to interpretation in archaeology. Cambridge: Cambridge University Press.

- 1990. The domestication of Europe. Cambridge: Cambridge University Press.

- 1991. Interpretive Archaeology. American Antiquity, 56 (1), pp. 7-18.

INGOLD, T. 1980. Hunters, pastoralists and ranchers. Cambridge: Cambridge University Press. 
- 1986. The appropriation of nature. Essays on human ecology and social relations. Manchester: Manchester University Press.

INFANTE ROURA, F., VAQUERO LASTRES, J. \& CRIADO BOADO, F. 1990. Vacas, caballos, abrigos y túmulos: definición de una geografía del movimento para el estudio arqueológico. Cuadernos de Estudos Galegos XL (105), pp. 21-39.

JORGE, S.O. 1986. Povoados da Pé-história recente da regiao de Chaves- $V^{a}$. Pa de Aguiar. Porto: Instituto de Arqueologia da Facultade de Letras do Porto.

- 1990. Respuesta a la recensión de M.L. Ruíz-Gálvez (1989). Trabajos de Prehistoria 47, pp. 143-6.

KUPER, A. 1988. The invention of primitive society. Transformations of an Illusion. London: Routledge.

LEVI-STRAUSS, C. 1963. The use of wild plants in tropical south America. In J.H. Steward (ed.), Handbook of south American indians. Vol. 6: Physical anthropology, linguistics and cultural geography of south American indians. New York: Cooper Square Publishers, Inc., pp. 465-86.

- 1964. El pensamiento salvaje. México: Fondo de Cultura Económica, (tercera reimpresión, 1975; La pensé sauvage, Paris: Plon, 1962).

- 1968. Mitológicas, I. Lo crudo y lo cocido. México: Fondo de Cultura Económica, (segunda reimpresión, 1978; Le cru et le cuit, Paris: Plon, 1964).

- 1972. Estructuralismo y ecología. Barcelona: Anagrama, (Structuralism and Ecology, New York: Barnard Alumnae, 1972).

- 1976. El hombre desnudo. México: Siglo XXI, (L'homme nu, Paris: Plon, 1971).

- 1979. Antropología estructural, 2. Mito, sociedad, humanidades. México: Siglo XXI, (Anthropologie structurale deux, Paris: Plon, 1973).

- 1986. La alfarera celosa. Barcelona: Paidos, (La poterie jalouse, Paris: Plon, 1985).

Lizot, J. 1977. PopulaÇao, recursos e guerra entre os Yanomami. Crítica da Antropología Ecológica. Libre 2: 161-97, (Paris: Payot).

- 1978. Economie primitive et subsistance. Essai sur le travail et l'alimentation chez les Yanomami. Libre, 4: 69-113, (Paris: Payot).

LÓPEZ SUEVOS, R. 1975. O papel do escedente agrícola na economía galega. In D. García-Sabell et al. A Galicia rural de encrucillada, Vigo: Galaxia.

LYOTARD, J.-F. 1988. La Diferencia. Barcelona: Gedisa, (Le Différend, Paris: Minuit, 1983).

MADISON, G.B. 1990. The hermeneutics of postmodernity. Bloomington: Indiana University Press.

MAMAMI CONDORI, C. 1989. History and Prehistory in Bolivia: what about the Indians? In R. Layton, Conflict in the Archaeology of Living Traditions. London: Unwin Hyman, pp. 46-59.

MÉNDEZ FERNÁNDEZ F. 1989. Yacimientos del campaniforme tardio del Valle del Pedriña (Sierra de O Bocelo): asentamiento y sociedad. Santiago: Fac. Xeografía e Historia, trabajo de inv. del tercer ciclo.

- 1992. Habitat y sociedad en el Bronce Inicial de la Sierra de O Bocelo. Boletín del Seminario de Arte y Arqueología; en prensa.

MITHEN, S. 1987. Prehistoric red deer hunting strategies: a cost-risk-benefit analysis with reference to Upper Paleolithic northern Spain and mesolithic Denmark.

- 1988. Looking and learning: Upper Paleolithic art and information gathering. World Archaeology 19 (3), pp. 297-327.

- 1990. Thoughful foragers. A study of prehistoric decision making. Cambridge: Cambridge University Press. 
NAREDO, J.M. 1987. La economía en evolución. Historia y perspectivas de las categorías básicas del pensamiento económico. Madrid: Siglo XXI de España.

NOCETE CALVO, F. 1989. El espacio de la coerción. La transición al Estado en las Campiñas del Alto Guadalquivir (España), 3000-1500 a.C. British Archaeological Reports (IS) 492, (Oxford: BAR).

OLSEN, B. 1987. Stability and change in Saami Band structure in the Varanger Area of Arctic Norway, AD 1300-1700. Norwegian Archaeological Review 20 (2), pp. 65-80.

OLSEN, B. 1988. Interaction between hunter-gatherers and farmers: ethnographical and archaeological perspectives. Archeologia Polski XXXIII, pp. 425-33.

PEÑA SANTOS, A. de la, 1989. El último milenio a.C. en el área gallega. Génesis y evolución del mundo castreño galaico a la luz de la Arqueología. Actas del Coloquio sobre Etnogénesis de la Península lbérica, (Madrid); en prensa.

- 1992. Castro de Torroso (Mos, Pontevedra). Síntesis de la Campañas de Excavaciones 19841990. Arqueoloxí-Memorias, 11. Santiago: Xunta de Galicia, Dirección Xeral do Patrimonio Histórico.

QUAINI, B. La construcción de la geografía humana. Barcelona: Oikos-Tau, (La construzione della Geografia humana, Firenze: Nuova Italia, 1981).

RUIZ-GÁLVEZ PRIEGO, M.L. 1989. Recensión del libro: S.O. Jorge, Povoados da Pé-história recente da regiao de Chaves- $V^{a}$. $P^{a}$. de Aguiar; (Porto, 1986). Trabajos de Prehistoria 46, pp. 32327.

SAHLINS, M. 1972. Las sociedades tribales. Barcelona: Edit. Labor, (New Jersey: Prentice-Hall).

- 1977. Economía de la Edad de Piedra. Madrid: Akal, (Chicago: Aldine Pub. Co., 1974).

SHANIN, T. 1987. Peasants and peasant societies. London: Penguin, ( $2^{\mathrm{a}}$ edic., $1^{\mathrm{a}}$ edic. 1971).

1990. Defining peasants. Oxford: Blackwells.

SHERRATT, A. 1990. The genesis of megaliths: monumentality, ethnicity and social complexity in Neolithic Nortwestern Europe. World Archaeology 22 (2), pp. 147-67.

SPERBER, D. 1985. On Anthropological knowledge. Cambrigde: Cambrigde University Press, (Paris: Hermann, 1982).

THOMAS, J. 1990. Monuments from the inside: the case of the irish megalithic tombs. World Archaeology 22 (2), pp. 168-77.

1991. Rethinking the Neolithic. Cambridge: Cambridge Univ. Press.

TILLEY, C. 1993. Historia y Crítica 3; en prensa. (Santiago).

TRICART, J. Y KILIAN, J. 1982. La eco-geografia y la ordenación del medio natural. Barcelona: Anagrama, (L'éco-géographie et l'aménagement du milie naturel, Paris: Maspero, 1979).

VAQUERO LASTRES, J. 1990. Ríos y tumbas. Reflexiones sobre el emplazamiento de los túmulos del NW. Trabalhos de Antropologia e Etnologia XXXV, pp. 151-68.

VEYNE, P. 1988. Foucault revoluciona la Historia. In P. Veyne, ¿Cómo se escribe la Historia? Madrid: Alianza Editorial.

VICENT GARCÍA, J. 1988. El origen de la economía productora. Breve introducción a la Historia de las Ideas. En P. López (coord.), El Neolítico en España, Madrid: Cátedra, pp. 11-58.

- 1990. El neolític: transformacions socials i económiques. En J. Anfruns y E. Llobet (eds.), El canvi cultural a la Prehistória, Barcelona: Columna, pp. 241-93.

1991. Fundamentos teórico-metodológicos para un programa de investigación arqueo-geográfica. En P. López (ed.), El cambio cultural del IV al II milenios a.C. en la comarca noroeste de Murcia, Madrid: Consejo Superior de Investigaciones Científicas. 
VIRILIO, P. 1974. Voz Espacio Social. In J. Duvignaud (dir.) La Sociología - Guía alfabética. Barcelona: Anagrama, (Paris: Ed. Denoël, 1972).

WAGSTAFF; J.M. 1987. Lansdscape and Culture. Geographical and Archaeological Perspectives. Oxford: Basil Blackwell.

WHITE, L. 1973. Tecnologia medieval y cambio social. Buenos Aires: Paidos, (Oxford: Oxford University Press, 1962).

WHITE, R. 1989. El pensamiento visual en la Edad del Hielo. Investigación y Ciencia, septiembre.

WOLF, E. 1982. Los campesinos. Barcelona: Labor, ( $3^{a}$ edic., $1^{a}$ eidc. en castellano 1971; New Jersey). 

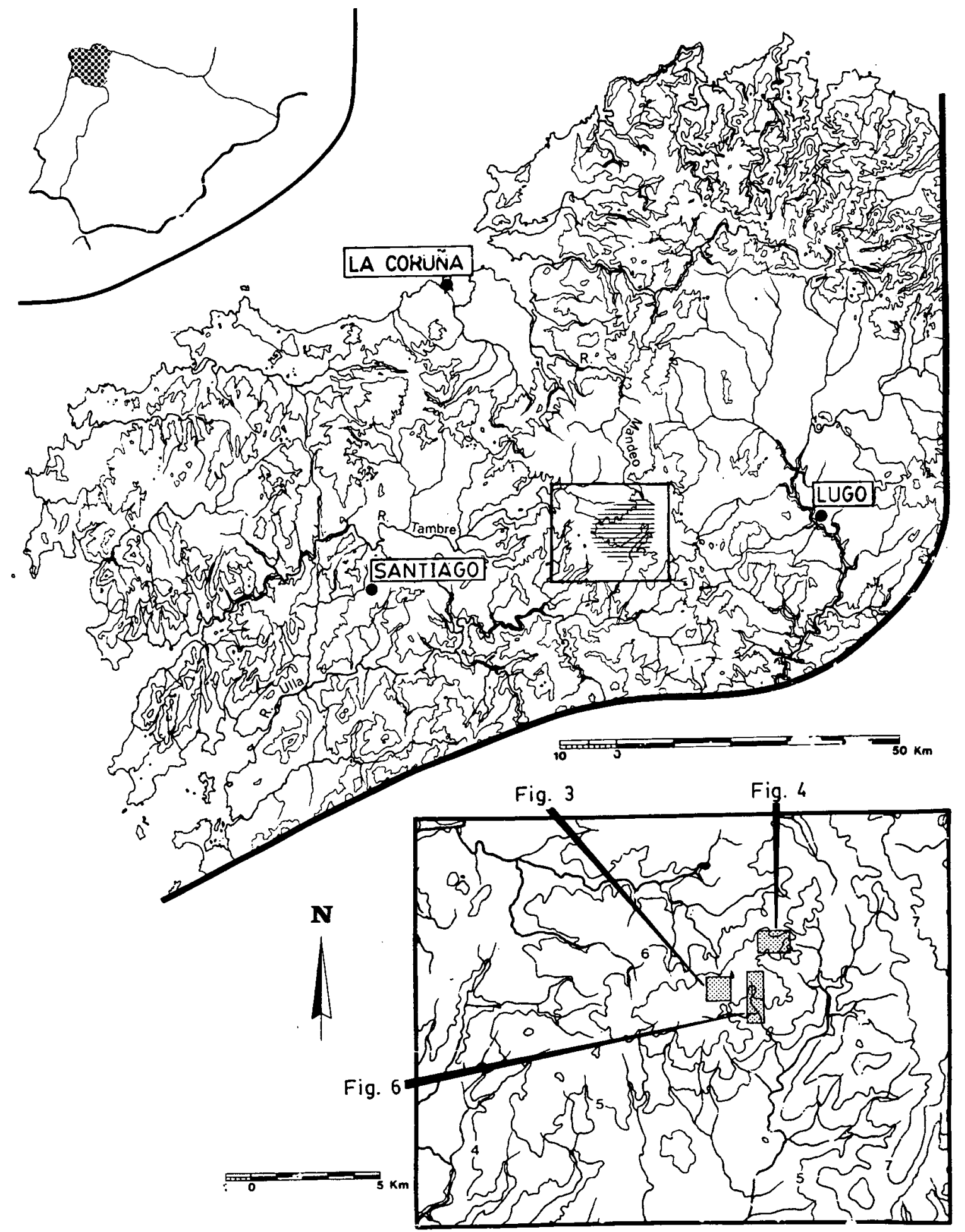

1. Situación de los ejemplos utilizados en las figuras 3, 4 y 6 para ilustrar los principales tipos de paisajes prehistóricos gallegos tratados en el texto. Todos los ejemplos proceden de la Sierra de $O$ Bocelo y han sido recuperados en el marco del proyecto Bocelo-Furelos de Arqueología del Paisaje. 


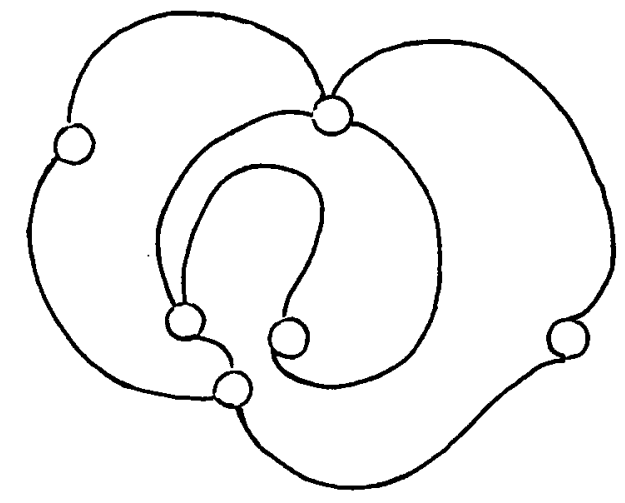

naturales líneas cerradas puntos cerrados red de espirales espacio abierto
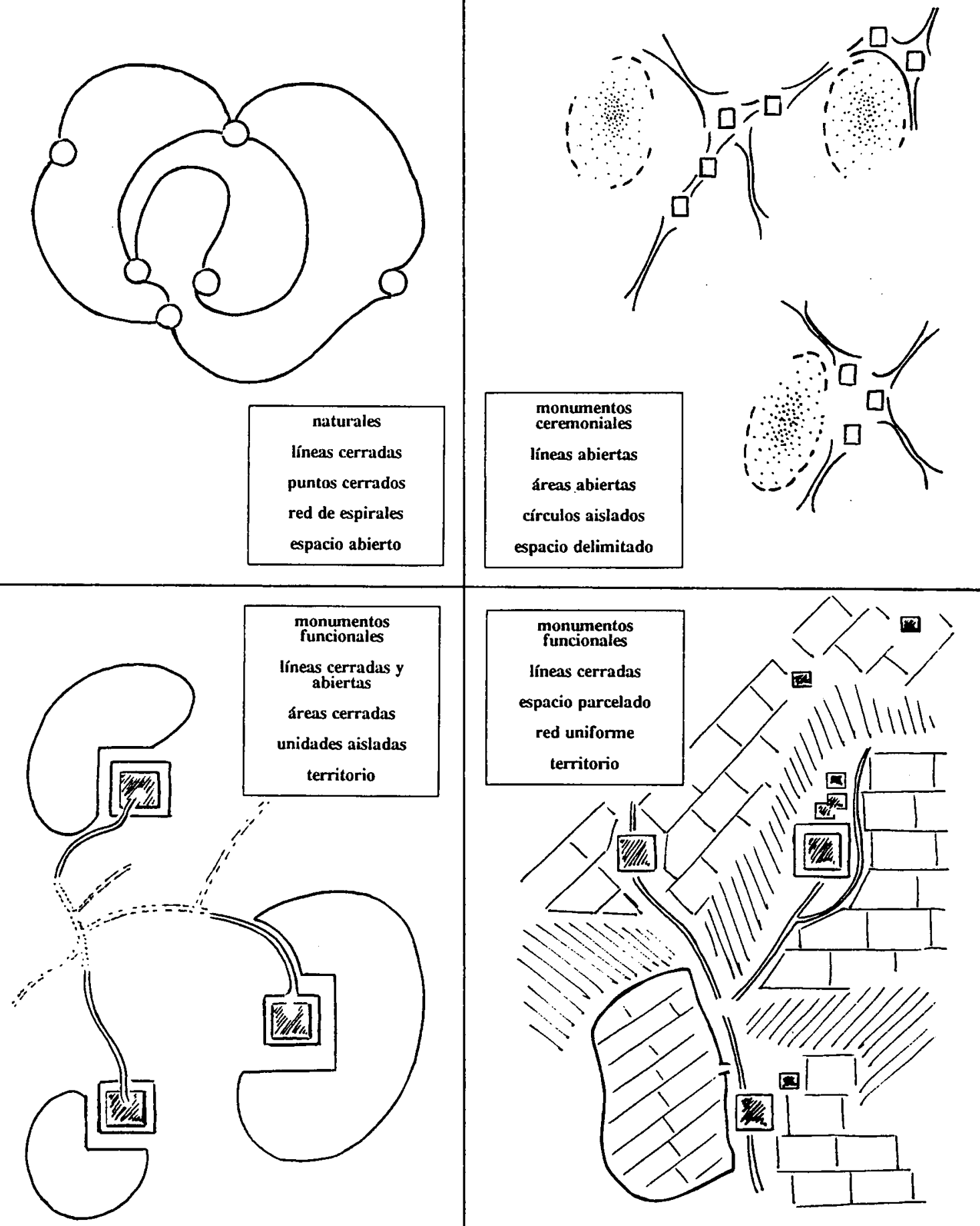

2. Esquema idealizado que intenta representar de forma gráfica las principales características de los modelos de construcción social del paisaje descritos en el apartado 2. del texto y concretados en el apartado 3. 

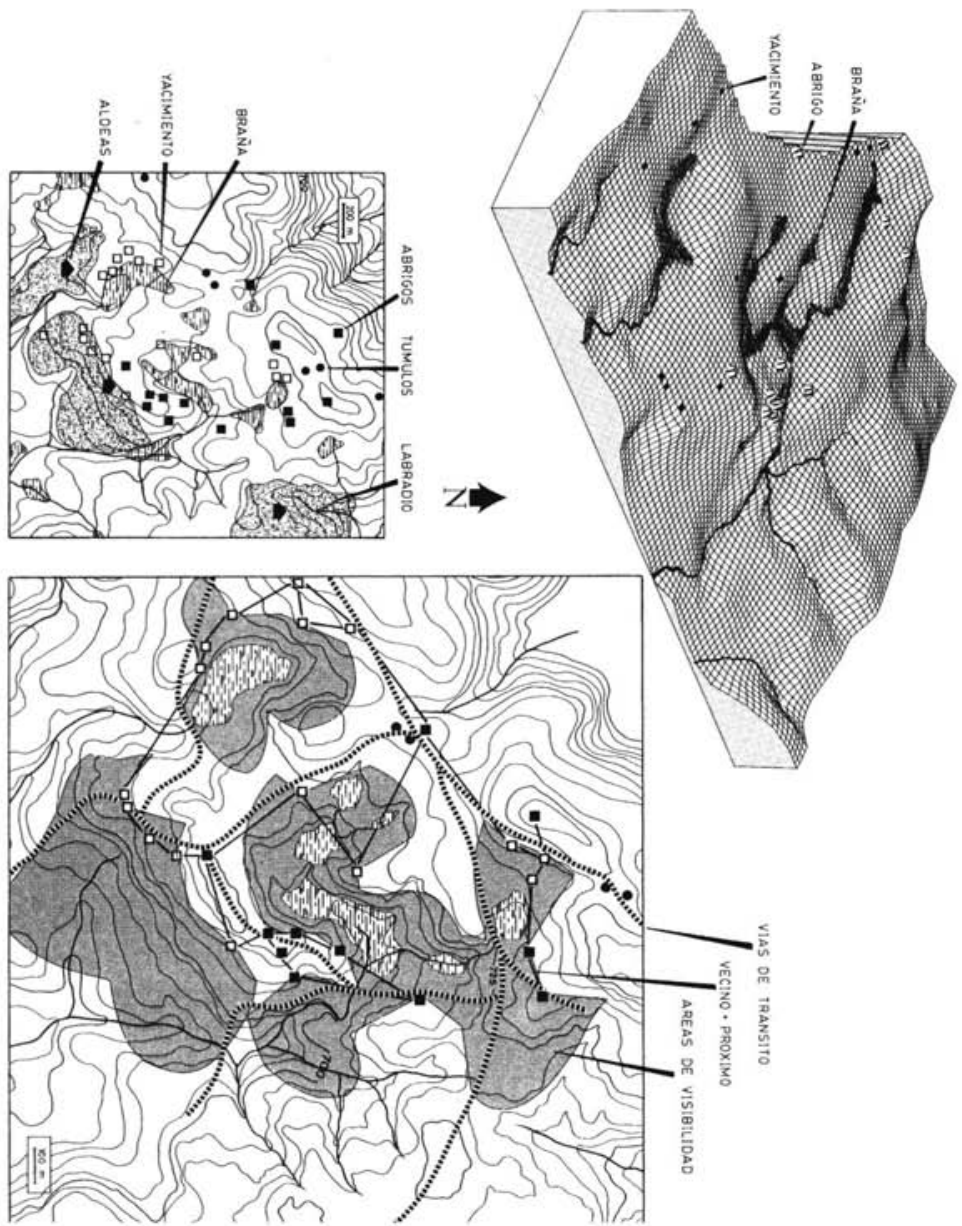

3. Ejemplo de configuración de un paisaje salvaje en momentos finales del Paleolítico Superior o Epipaleolíticos: se representan los abrigos y yacimientos descubiertos en la zona, su vinculación con las brañas anejas, el ámbito visual cubierto desde alguno de ellos, las principales afloraciones rocosas y la red de caminos y movimientos que interrelacionan todos los elementos anteriores. Los datos proceden del área de Abucide-Río de Ameneiros y han sido analizados arqueológicamente por D. Cerqueiro. (El tratamiento digital de la cartografia ha sido preparado por $\mathrm{F}$. Infante). 


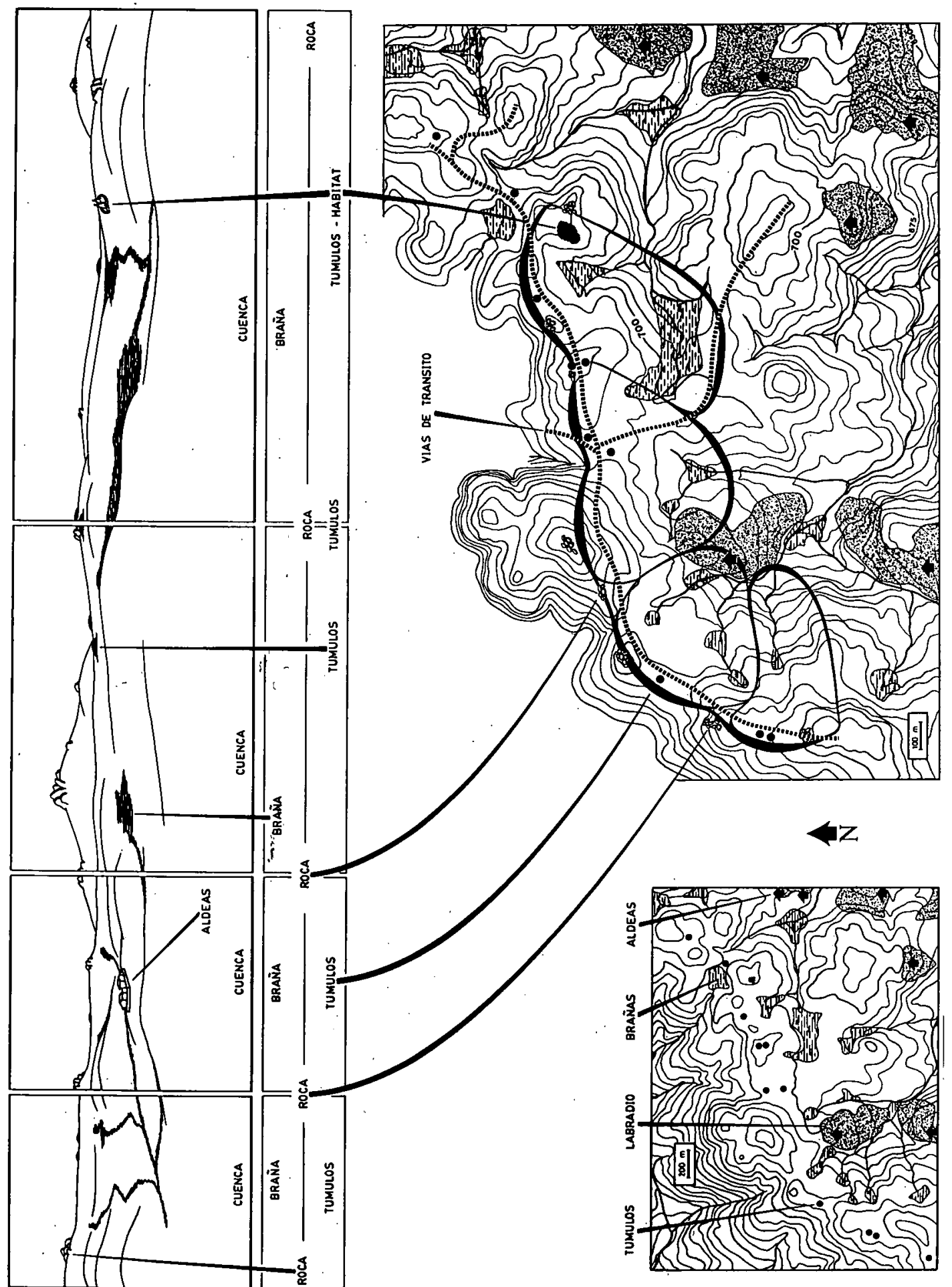

4. Ejemplo de configuración de un paisaje monumental en torno a un túmulo megalítico: se representan los factores esenciales de emplazamiento considerados en el texto. Los datos corresponden al conjunto tumular de Forno dos Mouros, en la zona de A Moruxosa y han sido analizados arqueológicamente por F. Criado, M. González y J. Vaquero. 


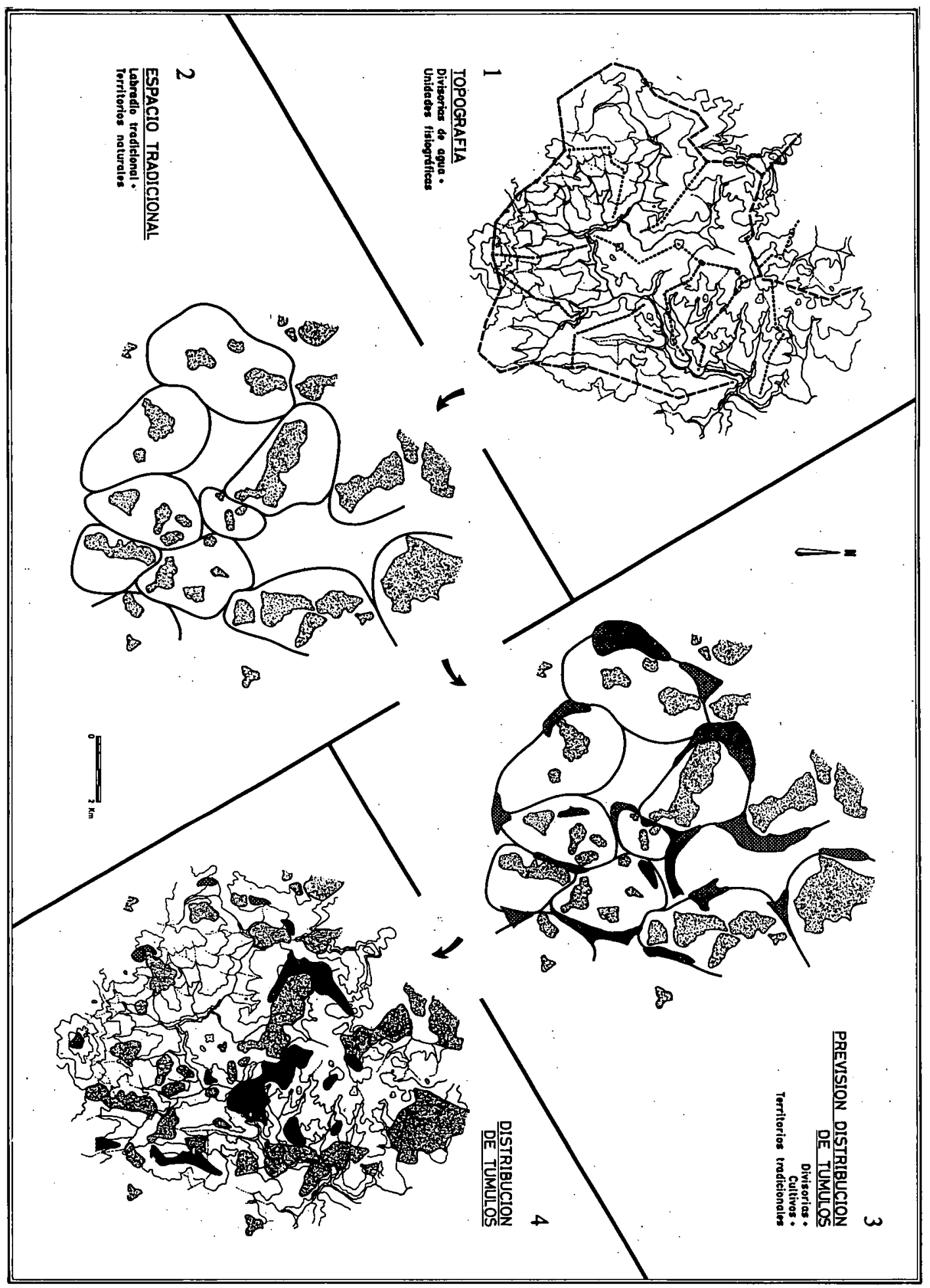

5. Ejemplo que muestra el efecto circular de un paisaje monumental y, a través de él, la definición de un espacio cerrado y delimitado. El ejemplo se basa en el ánalisis de la distribución y emplazamiento de los grupos de túmulos situados en la cuenca del río Deo (concellos de Aranga, Oza dos Ríos y Curtis, Coruña). La catalogación se puede consultar en Criado 1980. 


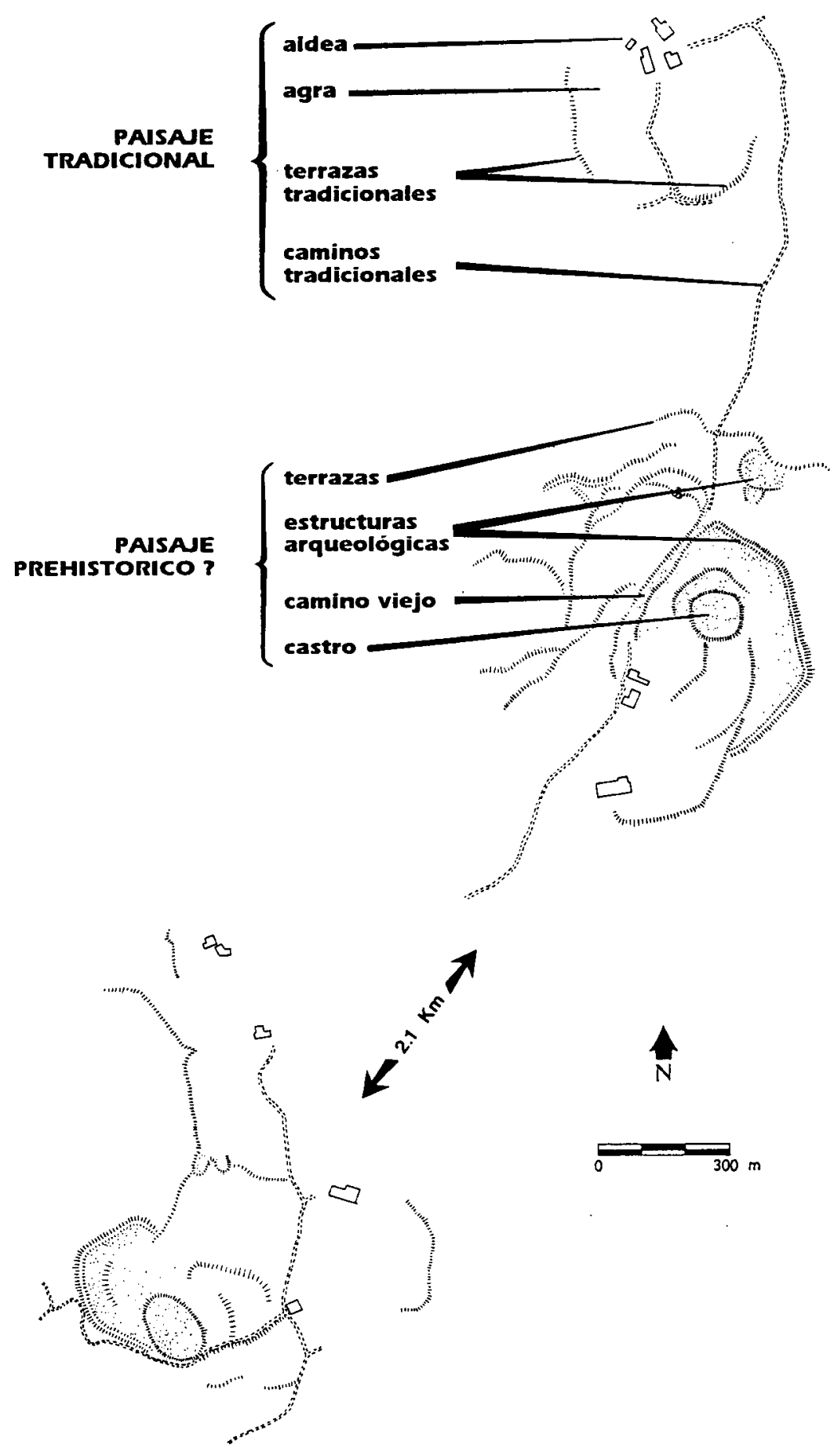

6. Ejemplo de configuración de un paisaje campesino fortificado en los alrededores de un asentamiento castreño: se representa la fortificación castreña, las posibles estructuras de parcelación del suelo anejas, las agras tradicionales situadas en sus proximidades y la red de caminos tradicionales que habrían podido estar en uso en época castreña. Los datos corresponden al Castro de Curros y a Castro de Lobos (parroquia de A Capela) y han sido analizados arqueológicamente por E. Rodríguez y R. Penedo. 